ano 16 - n. 63। janeiro/março - 2016

Belo Horizonte I p. 1-262 I ISSN 1516-3210

A\&C - R. de Dir. Administrativo \& Constitucional

Revista de Direito ADMINISTRATIVO \& CONSTITUCIONAL

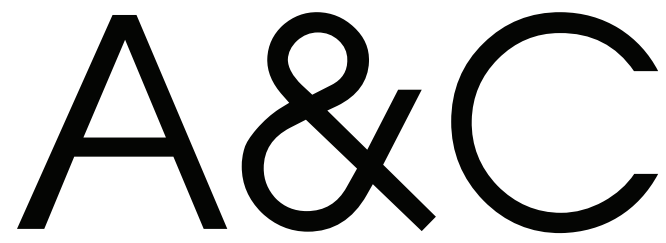




\section{A\&C - REVISTA DE DIREITO ADMINISTRATIVO \& CONSTITUCIONAL}

IPDA

Instituto Paranaense

de Direito Administrativo
ROMEU DELPE

BACELLAR

(c) 2016 Editora Fórum Ltda.

Todos os direitos reservados. É proibida a reprodução total ou parcial, de qualquer forma ou por qualquer meio eletrônico ou mecânico, inclusive através de processos xerográficos, de fotocópias ou de gravação, sem permissão por escrito do possuidor dos direitos de cópias (Lei no 9.610, de 19.02.1998).

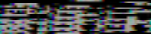

Luís Cláudio Rodrigues Ferreira

Presidente e Editor

Av. Afonso Pena, 2770 - 15a andar - Savassi - CEP 30130-012 - Belo Horizonte/MG - Brasil - Tel.: 08007043737 www.editoraforum.com.br / E-mail: editoraforum@editoraforum.com.br

Impressa no Brasil / Printed in Brazil / Distribuída em todo o Território Nacional

Os conceitos e opiniões expressas nos trabalhos assinados são de responsabilidade exclusiva de seus autores.

\begin{tabular}{|c|c|}
\hline A246 & $\begin{array}{l}\text { A\&C : Revista de Direito Administrativo \& } \\
\text { Constitucional. - ano 3, n. 11, (jan./mar. } \\
\text { 2003)- . - Belo Horizonte: Fórum, 2003- }\end{array}$ \\
\hline & Trimestral \\
\hline & $\begin{array}{l}\text { Ano 1, n. 1, } 1999 \text { até ano 2, n. 10, } 2002 \text { publicada } \\
\text { pela Editora Juruá em Curitiba }\end{array}$ \\
\hline & $\begin{array}{l}\text { 1. Direito administrativo. 2. Direito constitucional. } \\
\text { I. Fórum. }\end{array}$ \\
\hline & $\begin{array}{l}\text { CDD: } 342 \\
\text { CDU: } 342.9\end{array}$ \\
\hline
\end{tabular}

Coordenação editorial: Leonardo Eustáquio Siqueira Araújo Capa: Igor Jamur

Projeto gráfico e diagramação: Walter Santos

\section{Periódico classificado no Estrato A1 do Sistema Qualis da CAPES - Área: Direito.}

Revista do Programa de Pós-graduação do Instituto de Direito Romeu Felipe Bacellar (Instituição de Pesquisa e Pós-Graduação), em convênio com o Instituto Paranaense de Direito Administrativo (entidade associativa de âmbito regional filiada ao Instituto Brasileiro de Direito Administrativo). A linha editorial da $A \& C$ - Revista de Direito Administrativo \& Constitucional segue as diretrizes do Programa de Pós-Graduação do Instituto de Direito Romeu Felipe Bacellar em convênio com o Instituto Paranaense de Direito Administrativo. Procura divulgar as pesquisas desenvolvidas na área de Direito Constitucional e de Direito Administrativo, com foco na questão da efetividade dos seus institutos não só no Brasil como no direito comparado, com ênfase na questão da interação e efetividade dos seus institutos, notadamente América Latina e países europeus de cultura latina.

A publicação é decidida com base em pareceres, respeitando-se o anonimato tanto do autor quanto dos pareceristas (sistema double-blind peer review).

Desde o primeiro número da Revista, $75 \%$ dos artigos publicados (por volume anual) são de autores vinculados a pelo menos cinco instituições distintas do Instituto de Direito Romeu Felipe Bacellar.

A partir do volume referente ao ano de 2008 , pelo menos $15 \%$ dos artigos publicados são de autores filiados a instituições estrangeiras.

Esta publicação está catalogada em:

- Ulrich's Periodicals Directory

- RVBI (Rede Virtual de Bibliotecas - Congresso Nacional)

- Library of Congress (Biblioteca do Congresso dos EUA)

A\&C - Revista de Direito Administrativo \& Constitucional realiza permuta com as seguintes publicações: - Revista da Faculdade de Direito, Universidade de São Paulo (USP), ISSN 0303-9838

- Rivista Diritto Pubblico Comparato ed Europeo, ISBN/EAN 978-88-348-9934-2 
Diretor-Geral

Romeu Felipe Bacellar Filho

Diretor Editorial

Paulo Roberto Ferreira Motta

Editores Acadêmicos Responsáveis

Daniel Wunder Hachem

Ana Cláudia Finger

Assessor Editorial

Felipe Klein Gussoli

\section{Conselho Editorial}

Adilson Abreu Dallari (PUC-SP) Juan Pablo Cajarville Peluffo (Universidad de La República - Uruguai) ardo Schier (Instituto Bacellar) Justo J. Reyna (Universidad Nacional del Litoral - Argentina)

Alice Gonzalez Borges (UFBA) Juarez Freitas (UFRGS)

Carlos Ari Sundfeld (FGV-SP) Luís Enrique Chase Plate (Universidad Nacional de Asunción - Paraguai)

Carlos Ayres Britto (UFSE) Marçal Justen Filho (UFPR)

Adriana da Costa Ricardo Schier (Instituto Bacellar)
Alice Gonzalez Borges (UFBA)

Marcelo Figueiredo (PUC-SP)

Márcio Cammarosano (PUC-SP)

Carlos Delpiazzo (Universidad de La República - Uruguai) Cármen Lúcia Antunes Rocha (PUC Minas) Célio Heitor Guimarães (Instituto Bacellar) Celso Antônio Bandeira de Mello (PUC-SP) Clèmerson Merlin Clève (UFPR) Clovis Beznos (PUC-SP) Edgar Chiuratto Guimarães (Instituto Bacellar) Maria Cristina Cesar de Oliveira (UFPA)

Nelson Figueiredo (UFG)

Odilon Borges Junior (UFES)

Pascual Caiella (Universidad de La Plata - Argentina)

Emerson Gabardo (UFPR)

Paulo Eduardo Garrido Modesto (UFBA)

Paulo Henrique Blasi (UFSC)

Enrique Silva Cimma (Universidad de Chile - Chile) Eros Roberto Grau (USP)

Irmgard Elena Lepenies (Universidad Nacional del Litoral - Argentina) de La Coruña - Espanha)

Pedro Paulo de Almeida Dutra (UFMG)

Regina Maria Macedo Nery Ferrari (UFPR)

Rogério Gesta Leal (UNISC)

Rolando Pantoja Bauzá (Universidad Nacional de Chile - Chile)

Sergio Ferraz (PUC-Rio)

Valmir Pontes Filho (UFCE)

José Eduardo Martins Cardoso (PUC-SP)

José Luís Said (Universidad de Buenos Aires - Argentina) José Mario Serrate Paz (Universidad de Santa Cruz - Bolívia)

Yara Stroppa (PUC-SP)

\section{Homenagem Especial}

Guillermo Andrés Muñoz (in memoriam) Jorge Luís Salomoni (in memoriam) Julio Rodolfo Comadira (in memoriam) Lúcia Valle Figueiredo (in memoriam)

Manoel de Oliveira Franco Sobrinho (in memoriam) Paulo Neves de Carvalho (in memoriam) 


\title{
Estado Social, legitimidade democrática e o controle de políticas públicas pelo Supremo Tribunal Federal
}

\author{
José Luis Bolzan de Morais \\ Professor Titular do Programa de Pós-Graduação (Mestrado e Doutorado) em Direito da \\ Universidade do Vale do Rio dos Sinos (São Leopoldo - RS, Brasil). Pós-Doutor em Direito \\ pela Universidade de Coimbra, Doutor em Direito pela UFSC e Universidade de Montpellier \\ I, Mestre em Direito pela PUC-Rio. Procurador do Estado do Rio Grande do Sul. E-mail: \\ $<$ bolzan@hotmail.com>.
}

\section{Guilherme Valle Brum}

Doutorando em Direito pela Universidade do Vale do Rio dos Sinos (São Leopoldo - RS, Brasil). Mestre pelo UniCEUB/DF. Procurador do Estado do Rio Grande do Sul. E-mail: <gvbrum@gmail.com>.

\begin{abstract}
Resumo: 0 presente trabalho pretende avaliar a jurisprudência do Supremo Tribunal Federal em matéria de controle de políticas públicas. A avaliação tem como parâmetros textos de autores que escrevem sobre os limites e as crises do Estado Social e o conceito de legitimidade por reflexividade de Pierre Rosanvallon. A hipótese é a de que a cadeia de precedentes do Supremo Tribunal Federal que trata de políticas públicas apresenta um déficit de legitimidade. Essa jurisprudência pretende ser perfeccionista, mas deixa de atentar para a necessidade de as decisões incorporarem a faticidade dos casos por meio dos princípios e de respeitarem a integridade do direito, por isso não consegue legitimar-se reflexivamente.
\end{abstract}

Palavras-chave: Limites do Estado Social. Políticas públicas. Legitimidade por Reflexividade. Supremo Tribunal Federal.

Sumário: Introdução - 1 Interrogações sobre o Estado Social no contexto da teoria do Estado moderna: seus limites e possibilidades - $\mathbf{2}$ A legitimidade por reflexividade em Pierre Rosanvallon - 3 A jurisprudência do Supremo Tribunal Federal sobre controle de políticas públicas: "Constituição sem Estado" e déficit de legitimidade - Conclusão - Referências

\section{Introdução}

A Constituição da República de 1988 instituiu um Estado Social abrangente e ambicioso, que faz muitas promessas, desde a construção de uma sociedade solidária até a erradicação da pobreza e a redução das desigualdades sociais e regionais. Mas, como parece óbvio, esse Estado tem limites, que giram em torno da disputa entre necessidades sociais crescentes e recursos financeiros escassos. 0 cenário de limites se exacerba quando pensamos no desenho estrutural dessa modelagem 
estatal, voltado que é à prática de políticas de inclusão, em um ambiente econômico excludente. ${ }^{1}$ É dizer, um projeto confrontado pela transição da política de pleno emprego para a do equilíbrio de contas e do controle da inflação. ${ }^{2}$ Há aí uma espécie de paradoxo, com implicações das mais variadas ordens. Pretendemos analisar aqui uma pequena vertente dessas implicações possíveis: a forma como o Supremo Tribunal Federal vem lidando, no ambiente incerto da globalização econômica, com o paradoxo do Estado Social. A análise será feita a partir da jurisprudência que essa Corte Constitucional produziu em matéria de controle de políticas públicas, tendo como critério de avaliação o conceito de "legitimidade por reflexividade" de Pierre Rosanvallon.

$\mathrm{Na}$ tentativa de organizar, em uma estrutura lógica, os três eixos temáticos do trabalho - Estado Social, critério de legitimidade da jurisdição e exame da jurisprudência do STF -, o texto será desenvolvido em correspondentes três partes. Na primeira, apresentamos uma visão panorâmica da teoria contemporânea do Estado, dando conta das tensões e disputas em que está inserido o modelo de Welfare State e que têm levado os teóricos a interrogações sobre o seu futuro (e da própria figura do Estado enquanto tal). Há pressões externas e internas, públicas e privadas, que incidem sobre esse arranjo político-jurídico, as quais, para alguns autores, podem caracterizar indicativos de verdadeiras crises de gestão e de soberania. A segunda parte do artigo será dedicada a descrever o critério de aceitação da autoridade representativa dos magistrados, qual seja, o que Rosanvallon chama de "legitimidade por reflexividade", que implica a caracterização dos tribunais como "foro de princípios", que devem agir com "integridade" (Ronald Dworkin) e resgatar, precisamente por meio dos princípios, o "mundo prático" nas suas decisões. A última parte do texto enfrentará, finalmente, a pergunta: é possível dizer que a jurisprudência do Supremo Tribunal sobre controle de políticas públicas é reflexivamente legítima? A tentativa de resposta a essa indagação será argumentativamente conduzida pelas ideias apresentadas nas duas primeiras partes do estudo.

Cumpre adiantarmos um alerta ao leitor: a nossa análise ficará restrita à cadeia de precedentes criada em sede de controle difuso de constitucionalidade, no âmbito do qual o conflito se estabelece entre partes processuais propriamente ditas. Nesse tipo de controvérsia, o Poder Judiciário aborda a ação do Estado em concreto, dispondo sobre possíveis falhas de desempenho da execução da específica política pública objeto da lide. Com isso não desejamos afirmar que não seja possível, em controle concentrado de constitucionalidade, efetuar esse tipo de abordagem, mas

\footnotetext{
Na origem do Estado Social, o ambiente econômico era o do "velho" capitalismo de produção, em muito distinto do atual capitalismo financeiro.

2 Vide NUNES, António José Avelãs. O estado capitalista e as suas máscaras. 2. ed. Rio de Janeiro: Lumen Juris, 2013.
} 
não é o que comumente ocorre. Acreditamos que esse recorte metodológico não prejudicará o argumento, que se prende a um exame qualitativo da fundamentação decisória apresentada nos casos selecionados.

A hipótese, enfim, aqui trabalhada é a de que o Supremo Tribunal Federal vem apreciando mal as contendas sobre a (in)suficiência constitucional de políticas públicas desempenhadas pelos demais poderes da República. Ela fica aquém da sua obrigação de legitimar-se de forma reflexiva e acaba cuidando da problemática como se a chave para a validação de seu agir fosse um tipo de legitimidade eleitoral, típica das autoridades que compõem as estruturas do Executivo e do Legislativo. A conclusão geral, portanto, é de que urge um repensar da forma como a Corte Constitucional brasileira está atuando nessas complexas demandas, que envolvem os limites e possibilidades do Estado Social formatado pela Constituição da República de 1988 como Estado Democrático de Direito.

\section{Interrogações sobre o Estado Social no contexto da teoria do Estado moderna: seus limites e possibilidades}

O arranjo político-jurídico que se convencionou chamar "Estado Social” ou "Estado de Bem-Estar Social", surgido no transcurso da primeira metade do século XX e impulsionado após a Segunda Guerra Mundial, é o resultado do reconhecimento e da positivação dos direitos relativos às relações de produção e seus reflexos. É aquele Estado no qual as pessoas, independentemente de sua situação social, ostentam direitos que devem ser protegidos por meio de prestações públicas (saúde, previdência, moradia, ou seja, os chamados direitos sociais, prestacionais por excelência). ${ }^{3}$ Contemporaneamente, há autores que sustentam ter ocorrido, inclusive, uma espécie de complexificação nesse modelo estatal, o que o teria deixado com um perfil ainda mais interventor, em função de um "aprofundamento/transformação da fórmula, de um lado, do Estado de Direito e, de outro, do Welfare State”. Dizendo-o de outro modo, ao mesmo tempo em que a tradicional questão social permanece central, "há como que a sua qualificação pelo caráter transformador que agora se incorpora". Esse seria, pois, o formato do atual Estado Democrático de Direito, ainda

\footnotetext{
3 Ficaremos, para não fugir do objeto deste trabalho, com essa definição abrangente de Welfare State, o que nos permitirá o desenvolvimento do argumento. Mas não desconhecemos a discussão teórica em torno desse conceito. Como alerta Celia Lessa Kerstenetzky, "a convivência entre um conhecimento acumulado significativo sobre vários aspectos da ação pública na promoção de bem-estar como quer que se o defina e o avanço relativamente modesto na delimitação do próprio objeto constitui um dos aspectos mais intrigantes da literatura especializada". A estratégia da autora para, como diz, "demarcar" o conceito de Estado Social é utilizar-se "dos registros de datas e fatos relevantes indicativos da presença de suas 'condições mínimas' de existência, encontráveis nas reconstruções históricas usuais”. Vide KERSTENETZKY, Celia Lessa. Estado do Bem-Estar Social na Idade da Razão. A reinvenção do Estado Social no mundo contemporâneo. Rio de Janeiro: Elsevier, 2012.
} 
qualificado como "Social”, mas aprimorado por uma espécie de autoimposição de um "conteúdo utópico de transformação do status quo" rumo a uma sociedade menos desigual, com maior justiça social. ${ }^{4}$

A grande questão que se coloca, dado esse perfil contemporâneo do Estado Social, é sobre qual seria o locus mais apropriado para a promoção dessa mudança, dessa transformação do status quo. Naturalmente, diante de promessas prima facie não cumpridas pelo Poder Público e da consagração de direitos sociais no texto constitucional (tornando-se, portanto, judicializáveis), o Poder Judiciário passa a ser um participante mais frequente na concretização dos princípios e regras veiculadores de posições jurídicas fundamentais, como, por exemplo, as constantes do art. 6으 da Constituição de 1988. Mas isso não implica dizer que o Poder Judiciário seria o agente principal de uma revolução em busca de maior igualdade. ${ }^{5}$

O fato é que essa aproximação do dever ser do texto constitucional ao ser da realidade fática, em termos de direitos sociais, permanece tarefa primordial dos Poderes Executivo e Legislativo via políticas públicas, sendo por meio destas que o caminho rumo a uma sociedade menos desigual deve ser percorrido. A ligação políticas públicas-Estado Social é, nesse sentido, umbilical. No entanto, sem desconsiderar essa característica do atual modelo estatal, a literatura moderna que compõe o campo de estudo da teoria do Estado vem interrogando com cada vez mais frequência a "possibilidade transformadora" do Estado Social. Não bastasse o reconhecimento de que ele tem limites decorrentes, inclusive, de sua fórmula estruturante (economia de exclusão associada a políticas de inclusão), há quem sustente que esse arranjo vive mesmo crises profundas, ${ }^{6}$ não só em sua adjetivação, ${ }^{7}$ mas também em seu núcleo substantivo.

Com efeito, a partir de critério já clássico adotado, no contexto europeu, por Rosanvallon, ${ }^{8}$ é possível relacionarmos três crises estruturais por que estaria passando

4 MORAIS, José Luis Bolzan de. As crises do Estado e da Constituição e a transformação espaço-temporal dos direitos humanos. 2. ed. Porto Alegre: Livraria do Advogado, 2011. p. 543-560. Edição Kindle. No mesmo sentido: MORAIS, José Luis Bolzan de; STRECK, Lenio Luiz. Ciência política e teoria geral do Estado. 4. ed. Porto Alegre: Livraria do Advogado, 2004. p. 86-99.

5 Esse tema será abordado, em maior profundidade, na sequência deste texto. Adiantamos, porém, que o Supremo Tribunal Federal, curiosamente, parece ter tentado assumir, autorreferencialmente, a função de propulsor do alcance dos objetivos do Estado Democrático e Social de Direito (art. 3o da Constituição), pelo menos se tivermos em linha de conta a sua jurisprudência sobre controle de políticas públicas.

- A noção de "crise" não necessariamente carrega uma marca negativa (de fim, de destruição, de ruína). Pode, sim, aportar o novo, e este como momento inaugural em que tudo está "à disposição". Como anota Peter Pál Pelbart, ancorado em François Tosquelles: “El momento de la crisis, disse él, es aquel em el que ya nada parece posible. Pero también es el momento em que se cruzan muchas transformaciones [...] Es decir, la crisis es conjunción del 'nada es posible' y del 'todo es posible' [...]”. Ver: Una crisis de sentido es la condición necesária para que algo nuevo aparezca. In: FERNANDEZ-SAVATER, Amador. Fuera de lugar. Conversaciones entre crisis e transformación. Madrid: Acuarela y Machado Grupo de Distribución, 2013. p. 45-46.

7 Confira-se: CANOTILHO, Joaquim José Gomes. O Estado adjetivado e a teoria da Constituição. Revista da Procuradoria-Geral do Estado do Rio Grande do Sul, n. 56, p. 25-40, 2002.

8 ROSANVALLON, Pierre. A crise do Estado-providência. Tradução de Joel Pimentel de Ulhôa. Goiânia: UFG, 1997; ROSANVALLON, Pierre. A nova questão social. Repensando o Estado Providência. Tradução de Sérgio Bath. Brasília: Instituto Teotônio Vilela, 1998. 
o Estado Social: uma crise fiscal, uma crise ideológica e uma crise filosófica. ${ }^{9}$ A crise fiscal ou fiscal-financeira parece ter tido seu início na década de 1960, "quando os primeiros sinais de que receitas e despesas estão em descompasso, estas superando aquelas, são percebidos", intensificando-se a partir de 1970, oportunidade em que o desequilíbrio econômico se aprofunda pelo choque provocado entre o aumento das demandas em face do Estado e a crise econômica mundial (crise da matriz energética de base petroquímica). Esse modelo estatal convive hoje com uma espécie de círculo vicioso: crise econômica, debilidade pública e necessidades sociais. Tendo em vista as conjunturas econômicas e a transformação do capitalismo de produtivo à financeiro, muitas das situações provisórias, para as quais o Estado Social fora pensado, passaram a ser de longa duração. Políticas públicas forjadas para dar conta de problemáticas cíclicas específicas transformaram-se em políticas permanentes, ensejando prestações estatais duradouras e, portanto, intensificando a defasagem entre a poupança e os gastos públicos, peculiar ao projeto keynesiano.

Ao lado da crise fiscal-financeira - a principal delas -, estão as outras duas crises ditas estruturais. A crise ideológica, que direciona o olhar ao exame da legitimidade do Estado Social para dar conta dos desafios que se Ihe colocam e, portanto, pode ser caracterizada como um questionamento sobre a forma de organização e de gestão do Estado, tendo como pano de fundo um embate entre a democratização do acesso ao espaço público da política (que amplia e complexifica as demandas por prestações públicas) e a burocratização das fórmulas de atendimento a essas pretensões sociais. E a crise filosófica pela qual estaria passando o Welfare State, que se refere a uma desagregação de sua base, fundamentada no princípio da solidariedade. A base antropológica desse modelo estatal deveria estar composta por agentes dotados de "uma compreensão coletiva, compartilhada e compromissada de ser-estar no mundo". Porém, o que se constata é "a transformação do indivíduo liberal em cliente da administração, apropriando privadamente a poupança pública ou adotando estratégias assistencialistas de distribuição das respostas estatais e dos serviços públicos [...]". ${ }^{10}$

As crises e os limites do Estado Social podem ser endógenos ao modelo, mas também externos a ele. Externamente, podem advir dos influxos do mercado, próprios

\footnotetext{
9 E, além dessas crises estruturais, teríamos ainda a crise conceitual (o poder como soberania), a crise constitucional ou institucional (conflitos entre política, economia e direito), a crise funcional (os novos rearranjos decorrentes dos embates entre funções estatais) e a crise política (ou crise de representatividade). Um detalhamento maior sobre essas crises e a discussão sobre as suas controvertidas origens não serão abordados neste artigo, porquanto, embora se tratem de temas relevantes, não são necessários para a demonstração do argumento geral do texto. Vide: MORAIS, José Luis Bolzan de. As crises do Estado e da Constituição e a transformação espaço-temporal dos direitos humanos. 2. ed. Porto Alegre: Livraria do Advogado, 2011. p. 590-606. Edição Kindle.

10 MORAIS, José Luis Bolzan de. As crises do Estado e da Constituição e a transformação espaço-temporal dos direitos humanos. 2. ed. Porto Alegre: Livraria do Advogado, 2011. p. 618-666. Edição Kindle.
} 
do capitalismo financeiro, ou provir das inevitáveis relações político-econômicas com outras nações soberanas, o que nos leva a interrogar a própria noção de soberania das decisões tomadas em nome do Estado, mormente em tempos de intensa globalização econômica. Avelãs Nunes, por exemplo, em tom muito crítico, lamenta o enfraquecimento do Welfare State e a assunção, em diversas áreas de atuação social, de novas roupagens estatais (que ele chama de "máscaras do Estado capitalista"). A última delas, cognominada de "Estado garantidor", ${ }^{11}$ nascida no seio da social-democracia europeia, ocorre quando o Estado, pressionado por sua suposta ineficiência, assume a feição de mero "incentivador do mercado" ou "orientador de comportamentos". Deveria, nesse contexto, garantir a prestação dos serviços públicos essenciais à luz dos padrões civilizacionais da nossa época, mas, ao mesmo tempo, entregá-la a empresas privadas, que atuariam segundo os padrões do mercado. A ação do Estado seria, pois, subsidiária aos atores privados, mesmo nos serviços públicos essenciais, cabendo-Ihe apenas "proporcionar as condições para a otimização do mercado", por meio de "comandos específicos de corporate governance e responsabilidade social no direito das sociedades", a fim de que os atores privados se conduzam de acordo com a lei e as boas práticas empresariais. ${ }^{12}$

David Held, embora em linha de argumento diversa, também enfatiza a limitação dos Estados Nacionais para a resolução de problemas políticos em um mundo cada vez mais globalizado. ${ }^{13}$ Diz ele que "à medida que se aumentam as exigências ao Estado, vão surgindo conjuntos de problemas políticos que não podem ser adequadamente resolvidos sem a cooperação de outros Estados ou de atores não estatais". ${ }^{14}$ Com efeito, a globalização e as alterações na natureza e na forma de governança global colocam problemas referentes ao âmbito de aplicação da democracia e da jurisdição, tendo em conta que "a relação entre aqueles que tomam as decisões e aqueles que são afetados por elas não é necessariamente simétrica ou congruente no tocante ao território". E isso, claramente, impacta na execução de políticas públicas em nível nacional. ${ }^{15}$

11 Modelo de estado cujo desenvolvimento teórico original é atribuído por Avelãs Nunes a Joaquim José Gomes Canotilho. Aliás, boa parte das críticas tecidas no texto sob enfoque (NUNES, António José Avelãs. o estado capitalista e as suas máscaras. 2. ed. Rio de Janeiro: Lumen Juris, 2013) à nova roupagem do Estado capitalista são dirigidas às teses que Canotilho passou a adotar depois da conhecida virada em seu pensamento (pós-Constituição dirigente), de que é exemplo o seguinte texto do autor: CANOTILHO, Joaquim José Gomes. O Estado adjetivado e a teoria da Constituição. Revista da Procuradoria-Geral do Estado do Rio Grande do Sul, n. 56, p. 25-40, 2002.

12 NUNES, António José Avelãs. O estado capitalista e as suas máscaras. 2. ed. Rio de Janeiro: Lumen Juris, 2013, p. 187-191.

13 O autor define a globalização como “ampliação, intensificação, aceleração e aumento do impacto da interconectabilidade do mundo" (HELD, David. Cosmopolitismo. Ideales y realidades. Tradução de Dimitri Fernández Bobrovski. Madrid: Alianza Editorial, 2012. p. 39, tradução nossa).

14 HELD, David. Cosmopolitismo. Ideales y realidades. Tradução de Dimitri Fernández Bobrovski. Madrid: Alianza Editorial, 2012. p. 26, tradução nossa.

15 O seguinte excerto do texto de Held tem um bom poder explicativo geral acerca do fenômeno da globalização e de suas conexões com os arranjos institucionais e as relações sociais internas aos Estados: "A relação 
De um modo similar, Georg Sorensen, em sua obra que debate o "mito da retirada do Estado" no mundo contemporâneo, enfatiza que a globalização econômica apresenta problemas novos às políticas de bem-estar, o que pode ou não conduzir a restrições sobre essas políticas públicas. Segundo o autor, "o regime de bemestar se mantém, porém se transformou de forma a ser possível que estejam em perigo ao menos alguns aspectos das prestações materiais de bem-estar". ${ }^{16}$ Esse é, em parte, também o argumento de Saskia Sassen, para quem, no contexto da globalização, vêm sendo produzidas alterações profundas nos arranjos institucionais internos aos Estados. Ela critica os trabalhos que apresentam "o global e o nacional como esferas separadas" e postula que há componentes dos Estados nacionais que "constituem espaços estratégicos para a estruturação do global e, nesse processo, sofrem alterações fundacionais". ${ }^{17}$ Há, nesse processo, implicações diretas, sem dúvida, na formulação de políticas públicas próprias ao modelo de Estado Social.

Dito de outro modo, para além de seus déficits estruturais, hoje o projeto de Estado Social, sempre em realização, sofre também o influxo de mudanças superestruturais, do próprio capitalismo (de produção para financeiro; de localizado para globalizado), impondo uma transição do seu centro de atenções (das políticas

cambiante entre a globalização e o moderno estado-nação se caracteriza por cinco diretrizes. Todas indicam um aumento da extensão, intensidade, velocidade e impacto da globalização. E todas colocam importantes questões sobre o caráter da comunidade política democrática, em particular. Em primeiro lugar, a ideia de uma coletividade nacional autodeterminante - que delimita e conforma uma comunidade de destino - já não pode ser simplesmente colocada dentro das fronteiras de um só estado-nação. [...]. Em segundo lugar, já não se pode pressupor que o locus do poder político efetivo é sinônimo de governo nacional e de estado-nação; os estados nacionais e os governos nacionais estão agora integrados em complexas redes de poder político em nível regional e global [...]. O vínculo entre o governo efetivo, o autogoverno e um território delimitado está quebrado. Em terceiro lugar, [..] o direito de os estados de governar nos territórios delimitados - a sua soberania - não está a beira de um colapso, mas o caráter prático desse direito - a capacidade real dos estados de governar - está mudando sua forma. Está surgindo um novo regime de governo e de governança que se afasta das concepcões tradicionais de poder de Estado como uma forma indivisivel, territorialmente exclusiva de poder público. Em quarto lugar, o fomento e a melhoria do bem público requerem cada vez mais ações multilaterais coordenadas (por exemplo, para garantir a segurança ou para evitar as recessões globais). [...] O contexto das políticas públicas nacionais se transformou pela difusão da autoridade política e pelo aumento da governança em vários níveis (veja-se Nye y Donahue, 2000). Em quinto lugar, as distinções entre assuntos nacionais e estrangeiros, problemas políticos internos e assuntos externos são cada vez menos claras. [...] Por outro lado, temas como a localização e a estratégia de investimento das multinacionais, a regulação dos mercados financeiros globais, as ameaças às bases fiscais dos distintos países no contexto de uma divisão global do trabalho e a ausência de controles sobre capitais colocam perguntas sobre a vigência de alguns instrumentos-chave da política econômica nacional. De fato, em quase todas as áreas principais da política, a implicação das comunidades políticas nacionais nos fluxos e processos regionais e globais as obriga a uma intensiva coordenação e regulação transfronteiriças" (HELD, David. Cosmopolitismo. Ideales y realidades. Tradução de Dimitri Fernández Bobrovski. Madrid: Alianza Editorial, 2012. p. 45-47, tradução nossa).

16 SORENSEN, Georg. La transformación del Estado. Mas allá del mito del repliegue. Tradução de Ramón Cotarelo. Valencia: Tirant lo Blanch, 2010. p. 65, tradução nossa.

17 E isso quer dizer, para Sassen, que "à medida que o nacional de transforma em um espaço mais complexo para o funcionamento global, as histórias particulares de cada país não perdem, mas ganham importância, pois produzem negociações distintas com os novos fatores endógenos e exógenos das forças globais". Vide SASSEN, Saskia. Territorio, autoridad y derechos. De los ensamblajes medievales a los ensamblajes globales. Tradução de María Victoria Rodil. Madrid: Katz Editores, 2010. p. 288, tradução nossa. 
de pleno emprego para aquelas de equilíbrio de contas, como refere Avelãs Nunes), bem como do processo de "fim da geografia", como sugere Rodotà, fazendo transitar os centros decisórios de forma centrífuga (dos Estados Nacionais para instâncias extranacionais). ${ }^{18}$ Apesar disso, a figura do Estado ainda subsiste. E assim como teve suas origens em gestação muito antes de seu nascimento (na linha do que sustenta Sassen), vem convivendo com experimentos daquilo que Ihe poderá suplantar.

Parece possivel com isso termos por fixada pelo menos uma premissa do nosso argumento: há limites para a atuação do Estado Social enquanto formulador e executor de políticas públicas. O Estado se encontra hoje, talvez mais do que nunca, em um intenso jogo de tensões entre, para usar as expressões de Sassen, fatores endógenos e exógenos de constrangimento de sua ação, os quais vão desde o mercado de capitas até as incidências produzidas por outros países, principalmente por aqueles economicamente mais desenvolvidos. A composição desses interesses reflete-se no alcance das políticas públicas internas, tendo foros constitucionais próprios para sua realização. Tratando-se de escolhas antes políticas do que jurídicas, os poderes Legislativo e Executivo, legitimados que são democraticamente pelo voto, revelam-se as arenas deliberativas principais para delas cuidar (art. 1ํ, parágrafo único, da Constituição do Brasil). Aquele no momento da formulação legal da política, desenvolvendo a eficácia das normas constitucionais de cunho social, e este na implementação material das prestações decorrentes da legislação positivada.

É claro, contudo, que o Poder Judiciário participa desse jogo de tensões e interesses. Mas o faz subsidiariamente, apenas quando provocado. Por isso, parecenos que a questão fundamental, nessa ambiência, é saber que tipo de legitimidade detém os juízes quando chamados a intervir sobre políticas públicas, tendo em vista que não são agentes públicos eleitos, mas, ainda assim, exercem parcela de soberania (se é que essa expressão ainda tem um significado autoevidente). Enfim, qual o critério de validação de sua autoridade para atuar, ainda que subsidiariamente, nessa matéria? Há diversas propostas teóricas defendendo a possibilidade de o Poder Judiciário imiscuir-se nas escolhas alocativas dos demais Poderes quando detectadas violações à Constituição. Mas a pergunta sobre o tipo de legitimidade dos juízes permanece. E a indagação é importante, porque, na perspectiva defendida neste artigo, o tipo de legitimidade que autoriza o Poder Judiciário a deliberar sobre a (in)adequação constitucional de políticas públicas implicará a forma como o agir desse poder da República deve se desenvolver. Essa ideia deve ficar mais clara no desenvolvimento do próximo tópico do texto.

18 RODOTÀ, Stefano. I/ diritto di avere diritti. Roma: Laterza, 2012. 


\section{A legitimidade por reflexividade em Pierre Rosanvallon}

Em 2008, Pierre Rosanvallon lançou obra, amparada em densa pesquisa bibliográfica, sobre o problema da legitimidade no exercício do poder estatal. Nessa obra, intitulada $A$ legitimidade democrática: imparcialidade, reflexividade e proximidade, ${ }^{19} \mathrm{o}$ intelectual francês defende que a legitimidade democrática não está apenas no princípio majoritário. O princípio da maioria, segundo ele, forma apenas uma parte da legitimidade, que, se fosse restrita a esse princípio, seria muito incompleta. Há outras formas de aquisição de legitimidade (de "falar em nome da sociedade" ou de "ser representativo"), para além do procedimento da eleição: por "imparcialidade", por "reflexividade" e por "proximidade". Vejamos o que isso significa.

Ao longo da história, de acordo com Rosanvallon, duas foram as maneiras mais características de obtenção de legitimidade, pelo sufrágio universal e pela expertise da Administração Pública. À igualdade de expressão reconhecida pelo voto (eleição) corresponderia, em linhas muito gerais, o princípio da igualdade na admissão para funções públicas (concurso). Simultaneamente, esses dois tipos de "provas ou testes" paralelos foram consagrados para designar aqueles que podemos denominar representantes da generalidade social. A eleição como opção "subjetiva”, guiada pelo "sistema de interesses e opiniões", e o concurso como seleção "objetiva" dos mais competentes. Pode-se dizer que a primeira é um tipo de legitimidade "procedimental" e a segunda, "substancial". Rosanvallon descreve, com bons detalhes, o percurso histórico das marchas e contramarchas de cada dimensão da legitimidade, ora com mais atenção à vontade das urnas, ora enfocando uma vontade "mais racional" do poder, com ênfase aos servidores públicos de carreira, à burocracia. ${ }^{20}$

A tese do autor é a de que os três tipos de legitimidade que discrimina - por imparcialidade, reflexividade e proximidade - superpõem-se a essas duas dimensões da legitimidade, tendo, portanto, caráter híbrido, porquanto derivam das características das instituições, da sua capacidade para personalizar valores e princípios, porém, simultaneamente, continuam sendo dependentes do fato de que devem ser socialmente percebidas como tais. ${ }^{21}$ Rosanvallon entende que o governo da maioria, para que não seja assumido de uma maneira hipócrita e distanciada da realidade, deve ser prosaicamente compreendido como uma simples convenção empírica, cujo caráter está submetido a imposições superiores de justificação. Ele (o governo da maioria) se apoia no que se poderia chamar de uma legitimidade imperfeita, que,

\footnotetext{
19 ROSANVALLON, Pierre. La legitimidad democrática. Imparcialidad, reflexividad y proximidad. Tradução de Heber Cardoso. Barcelona: Paidós, 2010.

20 ROSANVALLON, Pierre. La legitimidad democrática. Imparcialidad, reflexividad y proximidad. Tradução de Heber Cardoso. Barcelona: Paidós, 2010. p. 24.

21 ROSANVALLON, Pierre. La legitimidad democrática. Imparcialidad, reflexividad y proximidad. Tradução de Heber Cardoso. Barcelona: Paidós, 2010. p. 29.
} 
portanto, necessita ser fortalecida por outros modos de legitimação democrática. "O povo eleitoral majoritário continua sendo um indubitável árbitro prático da vida democrática, dando-Ihe fundamento legal. Porém, agora só confere aos governantes uma legitimidade instrumental". ${ }^{22}$

Pois bem. É preciso, para avançarmos na abordagem do problema posto aqui, descrever brevemente os três tipos de legitimidade no pensamento do intelectual francês. 0 tipo que nos interessará com maior destaque será o da "legitimidade por reflexividade", que, em função da necessidade de organizar o argumento, será tratado por último. Começamos, então, pela "legitimidade por imparcialidade", que seria aquela atribuída às instituições ditas "autônomas", apartadas da Administração Pública "comum", e cujos melhores exemplos talvez sejam as agências reguladoras. 0 autor traz o contexto norte-americano de surgimento dessas agências e sustenta que "a debilidade da Administração e a vontade de romper com um universo minado pela corrupção foram os fatores que, nos EUA, criaram as condições para a implantação das primeiras autoridades públicas independentes". Isso quer dizer que, nos Estados Unidos de então, a suspeita de parcialidade correspondia a uma negação de legitimidade, o que teria levado, na prática, a que se começasse a distinguir uma legitimidade por imparcialidade da tradicional legitimidade eleitoral. $\mathrm{Na}$ França (década de 1980), segundo Rosanvallon, teria ocorrido fenômeno semelhante, com o "reconhecimento de que o poder político eleito não poderia ser considerado como gerente imparcial do interesse geral em um campo altamente sensível, como o da informação e da comunicação", para o qual, portanto, foi criado um órgão independente de regulação. ${ }^{23}$

O segundo tipo de legitimidade no pensamento de Pierre Rosanvallon, como adiantado, é a legitimidade por proximidade. Diversamente do que se passa com as legitimidades por imparcialidade e por reflexividade (esta que veremos a seguir), as quais pressupõem o desenvolvimento de novas instituições democráticas, a legitimidade por proximidade mais se aproxima de uma atitude do poder perante 0 povo, tendo seu foco no comportamento das autoridades. Está muito vinculada à ideia de justiça procedimental, ou seja, à forma como os cidadãos são tratados pelo Estado em um sentido processual, de conduta. Pressupõe equidade nas formas de trato. 0 autor se baseia em pesquisas realizadas por sociólogos do direito norteamericanos, como Tom Tyler, que indicam que o nível de confiança das pessoas nas instituições depende do procedimento com que estas atuam perante aquelas. Um grande estudo levado a cabo em Chicago, em 1984, com indivíduos que haviam

\footnotetext{
22 ROSANVALLON, Pierre. La legitimidad democrática. Imparcialidad, reflexividad y proximidad. Tradução de Heber Cardoso. Barcelona: Paidós, 2010. p. 37 e 109, tradução nossa.

23 ROSANVALLON, Pierre. La legitimidad democrática. Imparcialidad, reflexividad y proximidad. Tradução de Heber Cardoso. Barcelona: Paidós, 2010. p. 119-120, tradução nossa.
} 
tido causas policiais e judiciais colocou a atenção no fato de que a visão que tinham dessas instituições só apresentava uma débil correlação com o resultado, com a natureza das sanções empregadas, estando focada na percepção da equidade do processo. $^{24}$

Feito esse apanhado geral das legitimidades por imparcialidade e por proximidade, é possível abordarmos a espécie de legitimidade que nos interessará mais de perto, a que Pierre Rosanvallon chama de legitimidade por reflexividade. E, para descrevê-la, o autor parte da constatação inicial de que os elementos que estruturam a democracia têm como pano de fundo estas três suposições: a identificação da opção eleitoral com a expressão da vontade geral, a assimilação dos eleitores com o povo e o perdurável exercício da atividade política e parlamentar em continuidade ao momento eleitoral. Segundo Rosanvallon, a fragilidade desses enunciados não necessita de demonstração, porquanto patente as "reduções da realidade" que traduzem. $O$ trabalho de reflexividade consiste em corrigir esse caráter incompleto da democracia, instaurando mecanismos corretivos e compensadores desses três pressupostos. $^{25}$

Para desenvolver sua argumentação, o autor utiliza espécies de conceitos operacionais de "povo", os quais, legitimando o poder democrático, podem assumir estas três formas: "povo eleitoral", que toma a consistência numérica das urnas e se manifesta, de imediato, na divisão entre maioria e minoria; "povo social", que, ao contrário da formação episódica da maioria própria ao povo eleitoral, dá-se como uma sucessão ininterrupta de minorias ativas ou passivas (é a soma de protestos e iniciativas de toda natureza, uma exposição de situações vividas como manifestação do que faz e desfaz um mundo comum, um povo-fluxo, um povo-história, um povoproblema); e "povo princípio", constituído pelo equivalente geral que funda o projeto de inclusão de todos na sociedade. O povo princípio se reconduz ao princípio da igualdade, sendo um modo de composição "do comum", referindo-se, portanto, ao estatuto mínimo da pessoa, aos seus direitos fundamentais. Mas é preciso que se leve em conta uma importante advertência sobre essas divisões do fenômeno "povo": a generalidade social, considerada de maneira global, implica representar e superpor as três figuras, de modo que nenhuma delas, por si só, pode pretender encarnar adequadamente 0 "sujeito democrático". ${ }^{26}$

Aqui vale uma observação: essa classificação de povo do teórico francês dialoga em boa medida com o estudo produzido, no campo jurídico, por Friedrich

\footnotetext{
24 ROSANVALLON, Pierre. La legitimidad democrática. Imparcialidad, reflexividad y proximidad. Tradução de Heber Cardoso. Barcelona: Paidós, 2010. p. 234-236.

25 ROSANVALLON, Pierre. La legitimidad democrática. Imparcialidad, reflexividad y proximidad. Tradução de Heber Cardoso. Barcelona: Paidós, 2010. p. 173.

26 ROSANVALLON, Pierre. La legitimidad democrática. Imparcialidad, reflexividad y proximidad. Tradução de Heber Cardoso. Barcelona: Paidós, 2010. p. 181-184.
} 
Müller, que fala em "tipos" ou "esferas funcionais" de povo como possíveis fundamentadores do poder estatal. O primeiro é o que chama de "povo ativo", que corresponde ao grupo de eleitores, ou seja, os detentores dos direitos políticos. ${ }^{27}$ Na sequência, Müller apresenta o interessante conceito de "povo como instância global de atribuição de legitimidade". ${ }^{28}$ É essa esfera funcional de povo que legitima, com primazia, o agir de todos os Poderes da República, porque corresponde aos cidadãos enquanto destinatários desse agir, ou seja, a todos os atingidos pelos atos do Estado. Com mais razão ainda, portanto, deve ser a força legitimadora do agir dos Poderes Executivo e Judiciário, uma vez que “onde os funcionários públicos e juízes não chegam ao seu cargo por meio de uma eleição pelo povo, a sua ação se liga de forma demasiado etérea à ação originária do povo ativo". o povo como instância de atribuição não se refere ao mesmo aspecto do povo enquanto sujeito ativo. Todavia, só se pode falar enfaticamente em povo ativo quando vigem e são respeitados os direitos fundamentais individuais e políticos.

Müller ressalta, nesse sentido, que o povo enquanto instância legitimadora não pode degenerar-se em "povo como ícone", uma verdadeira deturpação da legitimidade democrática. O Estado Constitucional possui o monopólio do exercício legítimo do poder/violência. Decisões de autoridades estatais, especialmente daquelas encarregadas de executar e julgar (poderes Executivo e Judiciário), que tenham caráter de obrigatoriedade, devem poder ser atribuídas a textos de normas de forma convincente. A instância prolatora da decisão estatal (um tribunal, uma agência reguladora, por exemplo) que não se pode basear em textos de norma de modo plausivel exerce uma violência que ultrapassa o exercício do poder legítimo, "uma violência selvagem, transbordante, consistente tão-somente nesse ato que já não é constitucional". A invocação do povo, em um caso como esse, seria apenas icônica. ${ }^{29}$

Por fim, Friedrich Müller ainda fala sobre o "povo como destinatário das prestações civilizatórias do Estado". 30 Para o autor, esse tipo de povo é o mais abrangente, porque diz com a qualidade do ser humano, com a dignidade humana. Ele seria uma espécie de plus em relação ao povo enquanto instância global de atribuição de legitimidade porque não ficaria restrito aos "cidadãos", mas se expandiria aos "habitantes do Estado", valendo tanto para titulares de outras nacionalidades como para apátridas.

27 MÜLLER, Friedrich. Quem é o povo? A questão fundamental da democracia. Tradução de Peter Naumann. 3. ed. São Paulo: Max Limonad, 2003. p. 55-57. Ver também: MORAIS, José Luis Bolzan de. Crise do Estado e democracia. Onde está o povo? In: LIMA, Martonio Mont'Alverne Barreto; ALBUQUERQUE, Paulo Antonio de Menezes (Org.). Democracia, direito e política: estudos internacionais em homenagem a Friedrich Müller. Florianópolis: Conceito Editorial, 2006. p. 113-130.

28 MÜLLER, Friedrich. Quem é o povo? A questão fundamental da democracia. Tradução de Peter Naumann. 3. ed. São Paulo: Max Limonad, 2003. p. 59-64.

29 MÜLLER, Friedrich. Quem é o povo? A questão fundamental da democracia. Tradução de Peter Naumann. 3. ed. São Paulo: Max Limonad, 2003. p. 65-67.

30 MÜLLER, Friedrich. Quem é o povo? A questão fundamental da democracia. Tradução de Peter Naumann. 3. ed. São Paulo: Max Limonad, 2003. p. 75-77. 
Todos estão em posição de exigir do Estado o respeito aos direitos humanos. E a ação do Estado se legitimaria por esse respeito. Embora possa haver uma diferenciação de amplitude entre o povo como destinatário de prestações civilizatórias e o povo como instância atributiva de legitimidade, parece-nos que eles se sobrepõem, pelo menos em uma boa medida. É condição de legitimidade do agir estatal o respeito aos direitos fundamentais, ainda que se admita a discussão sobre a extensão de alguns desses direitos aos estrangeiros sem residência formal no Brasil. Precisamente por essas características, o povo como destinatário de prestações civilizatórias e o povo como instância atributiva de legitimidade são reconduzíveis ao conceito de povo princípio de Pierre Rosanvallon, com ele se identificando.

Seja como for, o fato é que, a partir de tais digressões, podemos depreender que a realidade da vida social é muito mais complexa do que se expressa nas urnas. As discussões e controvérsias se desenvolvem continuamente e em graus variados. Existem múltiplas arenas dispersas em diferentes lugares e instituições. Um abismo separa a querela dos experts (ou das contribuições científicas) das exaltações partidárias, das altercações pessoais e das conversas de bar. As eleições agregam esses diferentes elementos, convergindo-os na urna. Com isso, simplificam a complexidade da vida social em um momento específico, reduzindo "a multiplicação à unidade". Elas procedem a uma necessária condensação periódica dessa diversidade, mas, evidentemente, não a dissolvem. Isso equivale a dizer que as eleições não são capazes de absorver todos os elementos da complexidade social ao longo do tempo. E se assim o é, faz-se necessário continuar dando vida à complexidade social, fazendo com que a qualidade do debate público se mantenha e se desenvolva. A preocupação por ver prevalecer a razão pública em torno dessas multiplicações é tarefa da legitimidade por reflexividade. A generalidade social que a legitima, portanto, é uma "generalidade de multiplicação". ${ }^{31}$

As instituições por excelência da reflexividade são as Cortes Constitucionais, que atuam - se considerado o povo eleitoral - de maneira essencialmente contramajoritária. Elas têm como função primordial recordar que o soberano não se reduz a sua expressão eleitoral majoritária, de forma que representam a confrontação permanente entre os diferentes povos democráticos, principalmente o das urnas e o dos princípios. As Cortes Constitucionais, dessarte, possuem uma função propriamente reflexiva, que contribui para a formação de uma vontade comum, o que as distingue da imediatidade dos processos eleitorais (o povo princípio é permanente). Recordam, pois, os termos da construção de uma história. ${ }^{32}$

\footnotetext{
31 ROSANVALLON, Pierre. La legitimidad democrática. Imparcialidad, reflexividad y proximidad. Tradução de Heber Cardoso. Barcelona: Paidós, 2010. p. 186-187.

32 ROSANVALLON, Pierre. La legitimidad democrática. Imparcialidad, reflexividad y proximidad. Tradução de Heber Cardoso. Barcelona: Paidós, 2010. p. 195, 200 e 203.
} 
Rosanvallon sustenta que uma característica da legitimidade por reflexividade é reduzir a distância entre a democracia definida como um procedimento (urnas) e a democracia definida como um conteúdo (princípios). É uma dialética construtiva que obriga a maioria a sofisticar seus argumentos de princípio enquanto se encontra ameaçada pelos embates com a minoria, tendo como foro a justiça constitucional. A reflexividade é uma qualidade e não um estatuto, o que impõe seu exercício de legitimação constante pelo agir de suas instituições (uma espécie de legitimidade funcional). Em outras palavras, as Cortes Constitucionais devem se estabelecer socialmente por meio de uma contínua reafirmação de suas qualidades..$^{33}$

De uma maneira mais geral, a questão da legitimidade das instituições de tipo reflexivo e imparcial deve situar-se no marco do necessário dualismo democrático. A democracia, assim concebida, deve dar vida, ao mesmo tempo, a duas exigências: a de organização periódica de uma opção entre pessoas e programas fortemente diferenciados, por um lado, e a de implantação de instituições que garantam o interesse geral situadas por cima dessas diferenças, por outro. 0 perigo consiste em querer confundir esses dois registros. A institucionalização do conflito e as instituições de consenso devem coexistir em uma democracia bem ordenada. ${ }^{34}$ Parece-nos que, à luz dessas considerações, não deve ter ficado muito difícil perceber a proximidade da legitimidade por reflexividade de Pierre Rosanvallon com o conhecido pensamento de Ronald Dworkin sobre a atividade jurisdicional e os tribunais, aquela se desenvolvendo como um "romance em cadeia" que respeita a "integridade do Direito" e estes, como "foros de princípios".

Com efeito, em Dworkin, a legitimação da atuação do Poder Judiciário, principalmente das Cortes Constitucionais, dá-se por meio do respeito ao que chama de "integridade do Direito", virtude fundamental que consiste na exigência de que o Estado - ou mesmo a comunidade considerada como um agente moral - aja segundo um conjunto único e coerente de princípios, mesmo quando seus cidadãos estejam divididos quanto à exata natureza dos princípios de justiça e equidade corretos. Dworkin a separa em dois subtipos: a integridade na legislação, que pede aos que criam o direito que o mantenham coerente quanto aos princípios, e a integridade no julgamento, que pede aos responsáveis por decidir o que é a lei que a vejam e a façam cumprir com essa mesma coerência. ${ }^{35}$

33 ROSANVALLON, Pierre. La legitimidad democrática. Imparcialidad, reflexividad y proximidad. Tradução de Heber Cardoso. Barcelona: Paidós, 2010. p. 204.

34 ROSANVALLON, Pierre. La legitimidad democrática. Imparcialidad, reflexividad y proximidad. Tradução de Heber Cardoso. Barcelona: Paidós, 2010. p. 225.

35 DWORKIN, Ronald. O império do direito. Tradução de Jefferson Luiz Camargo. São Paulo: Martins Fontes, 2007. p. 200-203 e 229-230. Para uma aproximação desse ideário dworkiniano ao âmbito do controle judicial de políticas públicas, vide BRUM, Guilherme Valle. Uma teoria para o controle judicial de políticas públicas. Rio de Janeiro: Lumen Juris, 2014. p. 124-150. 
O direito como integridade é interpretativo. Aposta em que os juízes devam tentar enxergar a solução de problemas jurídicos segundo a sua melhor luz. Ou seja, interpretar o direito de modo a sempre melhorá-lo, a vê-lo mais justo ou, para utilizar a expressão de Rosanvallon, mais comprometido com o povo princípio. Nessa linha, Dworkin compara a construção ou a interpretação do direito com a elaboração de um "romance em cadeia", ${ }^{36}$ em que os juízes são igualmente atores e críticos. A cada decisão são introduzidos acréscimos na tradição interpretada, que assim vai sendo densificada e melhorada à medida que é sistematicamente reinterpretada. Cada um, portanto, “deve escrever seu capítulo de modo a criar da melhor maneira possível o romance em elaboração, e a complexidade dessa tarefa reproduz a complexidade de decidir um caso difícil de direito como integridade". Os romancistas-juízes têm de levar a sério seu labor de continuidade, devendo criar em conjunto, até onde for possível, um só romance unificado e da melhor qualidade possível. Ou seja, devem tentar criar o romance como se fosse obra de um único autor, e não como produto de muitas mãos diferentes, promovendo a coerência principiológica da comunidade a que pertencem.

É nessa ambiência que Ronald Dworkin faz menção - na linha de Rosanvallon, que inclusive o refere em seu texto ${ }^{37}$ - aos tribunais como "foros de princípios". Os tribunais e, em especial, as Cortes Constitucionais tomam decisões políticas importantes, mas o critério de validação de sua ação deve ser o respeito aos princípios e não à vontade da maioria. São, portanto, “decisões sobre que direitos as pessoas têm sob nosso sistema constitucional, não decisões sobre como se promove melhor o bem-estar geral". O Poder Judiciário deve agir elaborando e aplicando uma "teoria substantiva da representação, extraída do princípio básico de que o governo deve tratar as pessoas como iguais". ${ }^{38} \mathrm{E}$ a partir do momento em que assumimos que a legitimidade dos tribunais se dá por reflexividade, isto é, deve ter como critério o respeito ao povo princípio, há consequências importantes no que toca à qualidade e às características de sua atividade.

Lenio Streck aponta uma consequência importante nesse sentido. Para ele, os princípios instituem o mundo prático no direito, o que impõe ao juiz, ao deliberar, que faça uma reconstrução principiológica da história da comunidade a que pertence. Os tribunais devem ter em conta essa - diga-se assim - dimensão dos princípios. o mundo prático é "a manifestação existencial de uma comunidade de princípios". Daí a pertinente advertência de Streck: “nenhum princípio atua por si só como criador

\footnotetext{
36 DWORKIN, Ronald. O império do direito. Tradução de Jefferson Luiz Camargo. São Paulo: Martins Fontes, 2007. p. 275-279.

37 Vide ROSANVALLON, Pierre. La legitimidad democrática. Imparcialidad, reflexividad y proximidad. Tradução de Heber Cardoso. Barcelona: Paidós, 2010. p. 203.

38 DWORKIN, Ronald. Uma questão de princípio. Tradução de Luís Carlos Borges. São Paulo: Martins Fontes, 2005. p. 101.
} 
de normas, senão que unicamente possui força constitutiva ou valor construtivo em união com o conjunto do ordenamento reconhecido". Disso decorre a reconstrução institucional. "A institucionalização de um princípio demanda a constituição de uma tradição". ${ }^{39}$ Isso quer dizer que os juízes, para que se legitimem em seu labor, respeitando o tipo de legitimidade que Ines é apropriada (a legitimidade por reflexividade), devem, ao decidir, dar-se conta de que estão agregando um capítulo ao que Dworkin chama de "romance em cadeia", ou seja, estão reconstruindo principiologicamente a comunidade (o "povo princípio", diria Rosanvallon), de modo que não podem desconsiderar a dimensão fática, o mundo prático formado pela tradição e incorporado ao direito pelos princípios.

Parecem não ser mais necessárias maiores digressões sobre a legitimidade por reflexividade. A ideia é apenas introduzi-la ao leitor, nos estreitos limites deste artigo. É possível, por óbvio, problematizá-la em diversas vertentes. Mas, para prosseguirmos na abordagem do problema posto, basta que tenhamos clareza de que esse tipo de legitimidade demanda um olhar sobre os tribunais enquanto "foros de princípios", que devem resgatar a faticidade e traduzir a história da comunidade a que pertencem. Não representam o "povo eleitoral", tampouco o "povo social”, mas o "povo princípio", legitimando-se a partir desse último. A pergunta a ser respondida na última parte deste texto, na qual nos valeremos das considerações tecidas aqui e no tópico anterior (sobre os limites do Estado Social), é se a jurisprudência do Supremo Tribunal Federal em matéria de controle de políticas públicas é ou não reflexivamente "legítima", ou seja, se pode ser considerada como tradutora da voz do “povo princípio", sufragando a legitimação que Ihe é peculiar.

\section{A jurisprudência do Supremo Tribunal Federal sobre controle de políticas públicas: "Constituição sem Estado" e déficit de legitimidade}

A partir da classificação de Cass Sunstein, que divide os juízes, em relação à posição sobre a interpretação constitucional, em "fundamentalistas", "minimalistas", "perfeccionistas" e "majoritarianistas", não teríamos muitas dificuldades em situar a jurisprudência do Supremo Tribunal Federal em matéria de controle de políticas públicas na categoria "perfeccionista". ${ }^{40}$ Para Sunstein, os magistrados perfeccionistas pretendem fazer da Constituição "o melhor que ela pode ser", por meio da interpretação de seus vagos termos. Envolvem-se em discussões políticas,

\footnotetext{
39 STRECK, Lenio Luiz. Verdade e consenso. Constituição, hermenêutica e teorias discursivas. Da possibilidade à necessidade de respostas corretas em Direito. 3. ed. Rio de Janeiro: Lumen Juris, 2009. p. 528-530.

40 SUNSTEIN, Cass. Radicals in robes: why extreme right-wing courts are wrong for America. New York: Basic Books, 2005. p. 102-107, 418-506. Edição Kindle.
} 
morais e filosóficas profundas, teorizando sobre esses assuntos, transformando-os em direito. Comumente, criam novos direitos, dão-lhes significados abrangentes e praticam um modelo de interpretação constitucional ambicioso. A sua ideia é tentar resolver as grandes controvérsias sociais, posicionando-se sobre o devir histórico. ${ }^{41}$ De modo a confirmar, então, a sua caracterização como "perfeccionista”, vejamos o entendimento atualmente esboçado pelo Supremo Tribunal Federal acerca dos limites e possibilidades de o Poder Judiciário imiscuir-se em políticas públicas formatadas e implementadas pelos demais poderes da República: 42

EMENTA: AMPLIAÇÃO E MELHORIA NO ATENDIMENTO DE GESTANTES EM MATERNIDADES ESTADUAIS - DEVER ESTATAL DE ASSISTÊNCIA MATERNO-INFANTIL RESULTANTE DE NORMA CONSTITUCIONAL OBRIGAÇÃO JURÍDICO-CONSTITUCIONAL QUE SE IMPÕE AO PODER PÚBLICO, INCLUSIVE AOS ESTADOS-MEMBROS - CONFIGURAÇÃO, NO CASO, DE TÍPICA HIPÓTESE DE OMISSÃO INCONSTITUCIONAL IMPUTÁVEL AO ESTADO-MEMBRO - DESRESPEITO À CONSTITUIÇÃO PROVOCADO POR INÉRCIA ESTATAL (RTJ 183/818-819) - COMPORTAMENTO QUE TRANSGRIDE A AUTORIDADE DA LEI FUNDAMENTAL DA REPÚBLICA (RTJ 185/794-796) - A QUESTÃO DA RESERVA DO POSSÍVEL: RECONHECIMENTO DE SUA INAPLICABILIDADE, SEMPRE QUE A INVOCAÇÃO DESSA CLÁUSULA PUDER COMPROMETER O NÚCLEO BÁSICO QUE QUALIFICA O MÍNIMO EXISTENCIAL (RTJ 200/191-197) - O PAPEL DO PODER JUDICIÁRIO NA IMPLEMENTAÇÃO DE POLÍTICAS PÚBLICAS INSTITUÍDAS PELA CONSTITUIÇÃO E NÃO EFETIVADAS PELO PODER PÚBLICO - A FÓRMULA DA RESERVA DO POSSÍVEL NA PERSPECTIVA DA TEORIA DOS CUSTOS DOS DIREITOS: IMPOSSIBILIDADE DE SUA INVOCAÇÃO PARA LEGITIMAR O INJUSTO INADIMPLEMENTO DE DEVERES ESTATAIS DE PRESTAÇÃO CONSTITUCIONALMENTE IMPOSTOS AO ESTADO - A TEORIA DA “RESTRIÇÃO DAS RESTRIÇÕES" (OU DA "LIMITAÇÃO DAS LIMITAÇÕES") - CARÁTER COGENTE E VINCULANTE DAS NORMAS CONSTITUCIONAIS, INCLUSIVE DAQUELAS DE CONTEÚDO PROGRAMÁTICO, QUE VEICULAM DIRETRIZES DE POLÍTICAS PÚBLICAS, ESPECIALMENTE NA ÁREA DA SAÚDE (CF, ARTS. 196, 197 E 227) - A QUESTÃO DAS “ESCOLHAS TRÁGICAS” - A COLMATAÇÃO DE OMISSÕES INCONSTITUCIONAIS COMO NECESSIDADE INSTITUCIONAL FUNDADA

\footnotetext{
41 O autor coloca Dworkin como um defensor das posturas perfeccionistas. Há um tom evidentemente crítico, por parte de Cass Sunstein, acerca do perfeccionismo. Não nos posicionaremos sobre o assunto. Mas também não colocaremos, aprioristicamente, uma carga valorativa negativa sobre esse tipo de postura judicial, pois não o vemos como um problema em si. O que consideramos equivocada é a forma como o Supremo Tribunal Federal vem exercendo a interpretação perfeccionista - ou pretendente a perfeccionista - da Constituição quando em jogo controvérsias sobre políticas públicas. Afirmamos, desde já, que sua conduta fica muito aquém do necessário para respeitar a exigência de legitimar-se reflexivamente, na linha do que sustentam Rosanvallon e o próprio Dworkin.

42 Disponível em: <http://www.stf.jus.br>. Acesso em: 31 ago. 2014. Não parece demais relembrarmos, neste momento, tal como adiantado na introdução do trabalho, que a nossa análise ficará restrita à cadeia de precedentes criada em sede de controle difuso de constitucionalidade, ou seja, em sede de recurso extraordinário e de outros meios de insurgência não objetivos, os quais, por tratarem de conflitos entre partes processuais propriamente ditas, ensejam uma abordagem da ação do Estado em concreto, espaço privilegiado para o exame de possíveis falhas de desempenho da execução da política pública objeto da lide.
} 
EM COMPORTAMENTO AFIRMATIVO DOS JUÍZES E TRIBUNAIS E DE QUE RESULTA UMA POSITIVA CRIAÇÃO JURISPRUDENCIAL DO DIREITO - CONTROLE JURISDICIONAL DE LEGITIMIDADE DA OMISSÃO DO ESTADO: ATIVIDADE DE FISCALIZAÇÃO JUDICIAL QUE SE JUSTIFICA PELA NECESSIDADE DE OBSERVÂNCIA DE CERTOS PARÂMETROS CONSTITUCIONAIS (PROIBIÇÃO DE RETROCESSO SOCIAL, PROTEÇÃO AO MÍNIMO EXISTENCIAL, VEDAÇÃO DA PROTEÇÃO INSUFICIENTE E PROIBIÇÃO DE EXCESSO) - DOUTRINA - PRECEDENTES DO SUPREMO TRIBUNAL FEDERAL EM TEMA DE IMPLEMENTAÇÃO DE POLÍTICAS PÚBLICAS DELINEADAS NA CONSTITUIÇÃO DA REPÚBLICA (RTJ 174/687 - RTJ 175/1212-1213 - RTJ 199/1219-1220) - POSSIBILIDADE JURÍDICO-PROCESSUAL DE UTILIZAÇÃO DAS “ASTREINTES” (CPC, ART. 461, §5) COMO MEIO COERCITIVO INDIRETO - EXISTÊNCIA, NO CASO EM EXAME, DE RELEVANTE INTERESSE SOCIAL - AÇÃO CIVIL PÚBLICA: INSTRUMENTO PROCESSUAL ADEQUADO À PROTEÇÃO JURISDICIONAL DE DIREITOS REVESTIDOS DE METAINDIVIDUALIDADE - LEGITIMAÇÃO ATIVA DO MINISTÉRIO PÚBLICO (CF, ART. 129, III) - A FUNÇÃO INSTITUCIONAL DO MINISTÉRIO PÚBLICO COMO “DEFENSOR DO POVO” (CF, ART. 129, II) - DOUTRINA - PRECEDENTES - RECURSO DE AGRAVO IMPROVIDO. (RE no 581.352 AgR. Segunda Turma. Rel. Min. Celso de Mello. Julg. 29.10.2013. Acórdão eletrônico DJe, 230. Divulg. 21.11.2013. Public. 22.11.2013)

A política tratada nesse caso era o atendimento a gestantes em maternidades públicas. O Poder Judiciário, detectando insuficiências na prestação desse serviço, determinou ao Poder Executivo a sua ampliação e melhoria. Houve claras pretensões perfeccionistas nas razões de decidir. Foi referido ser possível ao Tribunal sindicar "a omissão inconstitucional imputável ao estado-membro" pelo "desrespeito à Constituição provocado por inércia estatal". Menções foram feitas no sentido de que reserva do possível é inaplicável "sempre que a invocação dessa cláusula puder comprometer o núcleo básico que qualifica o mínimo existencial”, de modo que esse exame seria "papel do Poder Judiciário na implementação de políticas públicas instituídas pela Constituição e não efetivadas pelo poder público". Além disso, foram feitas fortes exortações aos magistrados para casos futuros, como esta: "a colmatação de omissões inconstitucionais como necessidade institucional fundada em comportamento afirmativo dos juízes e tribunais e de que resulta uma positiva criação jurisprudencial do direito". Houve também definições sobre a "atividade de fiscalização judicial" de políticas públicas, que se justificaria "pela necessidade de observância de certos parâmetros constitucionais (proibição de retrocesso social, proteção ao mínimo existencial, vedação da proteção insuficiente e proibição de excesso)".

Esse é um padrão decisório verificado com muita frequência na jurisprudência do Supremo Tribunal Federal. Ora com uma retórica exagerada, ora com um discurso mais comedido, o núcleo das razões de decidir do Tribunal, quando em jogo o controle 
de políticas públicas, é o acima transcrito. Uma modelagem de decisão nesse sentido, mas mais resumida, também vem sendo recorrentemente utilizada no universo recente de julgados da Corte Constitucional. 0 texto de ementa abaixo reproduzido foi encontrado em, pelo menos, vinte e uma (21) situações, entre os anos de 2009 e 2014, a partir de pesquisa no site do Supremo Tribunal Federal, ${ }^{43}$ com ligeiras - e insignificantes - alterações redacionais entre as ocorrências:

Ementa: AGRAVO REGIMENTAL NO RECURSO EXTRAORDINÁRIO. POLÍTICAS PÚBLICAS. SEGURANÇA PÚBLICA. DETERMINAÇÃO PELO PODER JUDICIÁRIO. LIMITES ORÇAMENTÁRIOS. VIOLAÇÃO À SEPARAÇÃO DOS PODERES. INOCORRÊNCIA. AGRAVO A QUE SE NEGA PROVIMENTO. I - A jurisprudência desta Corte entende ser possível ao Poder Judiciário determinar ao Estado a implementação, em situações excepcionais, de políticas públicas previstas na Constituição sem que isso acarrete contrariedade ao princípio da separação dos poderes. II - Quanto aos limites orçamentários aos quais está vinculado o recorrente, o Poder Público, ressalvada a ocorrência de motivo objetivamente mensurável, não pode se furtar à observância de seus encargos constitucionais. III - Agravo regimental a que se nega provimento. (RE o 768.825 AgR. Segunda Turma. Rel. Min. Ricardo Lewandowski. Julg. 12.8.2014. Acórdão eletrônico DJe, 161. Divulg 20.8.2014. Public. 21.8.2014)

É uma versão mais sintética, mas com não menos pretensões perfeccionistas. 0 inteiro teor de cada um dos acórdãos confirma isso. Não poderão, à evidência, ser aqui transcritos, mas são de facílimo acesso. ${ }^{44} \mathrm{O}$ excerto fundamental desse padrão de decisão é este: "A jurisprudência desta Corte entende ser possível ao Poder Judiciário determinar ao Estado a implementação, em situações excepcionais, de políticas públicas previstas na Constituição sem que isso acarrete contrariedade ao princípio da separação dos poderes".

Com efeito, se empreendermos uma consulta ao site do Supremo Tribunal Federal, na base de dados que engloba apenas julgamentos colegiados, utilizando a expressão "políticas públicas", encontraremos 116 (cento e dezesseis) ocorrências, mas muitas delas não tratam de casos de judicialização da política, tendo o termo sido empregado em asserções marginais. ${ }^{45}$ Dessa totalidade, 41 (quarenta e uma) ${ }^{46}$

\footnotetext{
43 Disponivel em: <http://www.stf.jus.br>. Acesso em: 31.8.2014.

$44 \mathrm{O}$ inteiro teor de todos os acórdãos citados pode ser facilmente consultado no site do STF: <http://www.stf. jus.br>.

$45 \mathrm{Em} \mathrm{31.8.2014.}$

46 São estes os casos: RE no 410.715, RE no 436.996, STA no 223, Al no 664.053, RE no 595.595, RE no 594.018, RE no 464.143, RE no 603.575, RE no 367.432, Al no 734.487, RE no 607.381, RE no 559.646, ARE no 639.337, Al no 750.768, ARE o 635.679, Al no 708.667, Al no 593.676, RE no 417.408, RE no 665.764, RE no 634.643, Al no 809.018, RE no 642.536, RE no 563.144, RE no 700.227, Al no 835.956, Al no 829.984, AI no 810.410, RE no 628.159, RE no 763.667, RE no 795.749, RE no 440.028, RE no 581.352, ARE no 740.800, Al no 598.212, RE no 722.778, RE no 658.171, Al no 739.151, RE no 595.129, ARE no 761.127 , RE no 723.578 , RE ํo 768.825 .
} 
representam o entendimento que, hoje, consolidou-se na Corte, representado pelas ementas acima transcritas - tanto pela modelagem decisória mais detalhada como pela mais sintética. A primeira ocorrência representativa desse entendimento foi encontrada, considerada apenas a base de pesquisa em órgãos colegiados, no ano de 2005, quando do julgamento do Recurso Extraordinário (RE) o 410.715, da relatoria do Ministro Celso de Mello.

Contudo, embora esses dados objetivos indiquem que o primeiro precedente no qual a ementa apresentou a expressão "políticas públicas" e que tratou, efetivamente, do tema do controle judicial remonte a 2005, não é fácil encontrarmos um marco seguro que dê conta do momento no qual o Supremo Tribunal Federal passou a adotar a atual postura perfeccionista na matéria. A julgar pelas razões de decidir dos precedentes, há fortes indícios de que essa tradição teve seu nascedouro em uma decisão monocrática do ministro Celso de Mello proferida, em 2004, nos autos da Arguição de Descumprimento Fundamental (ADPF) nำ45. Foi a primeira ocorrência na qual se pôde verificar, de modo claro, o oferecimento de diretrizes perfeccionistas sobre o controle judicial de políticas públicas, diretrizes essas incorporadas por todos os precedentes que Ihe seguiram, muitos deles fazendo referência expressa à ADPF. Para bem ilustrar essa postulação, permitimo-nos transcrever, ainda que extensa, parte da decisão: ${ }^{47}$

[...] não posso deixar de reconhecer que a ação constitucional em referência, considerado o contexto em exame, qualifica-se como instrumento idôneo e apto a viabilizar a concretização de políticas públicas, quando, previstas no texto da Carta Política, tal como sucede no caso (EC 29/2000), venham a ser descumpridas, total ou parcialmente, pelas instâncias governamentais destinatárias do comando inscrito na própria Constituição da República. [...]

É certo que não se inclui, ordinariamente, no âmbito das funções institucionais do Poder Judiciário - e nas desta Suprema Corte, em especial - a atribuição de formular e de implementar políticas públicas (JOSÉ CARLOS VIEIRA DE ANDRADE, "Os Direitos Fundamentais na Constituição Portuguesa de 1976”, p. 207, item n. 05, 1987, Almedina, Coimbra), pois, nesse domínio, o encargo reside, primariamente, nos Poderes Legislativo e Executivo.

Tal incumbência, no entanto, embora em bases excepcionais, poderá atribuir-se ao Poder Judiciário, se e quando os órgãos estatais competentes, por descumprirem os encargos político-jurídicos que sobre eles incidem, vierem a comprometer, com tal comportamento, a eficácia e a integridade de direitos individuais e/ou coletivos impregnados de estatura constitucional, ainda que derivados de cláusulas revestidas de conteúdo programático. [...]

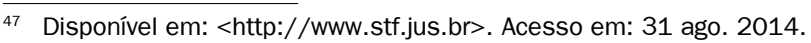


Não se mostrará lícito, no entanto, ao Poder Público, em tal hipótese - mediante indevida manipulação de sua atividade financeira e/ou político-administrativa - criar obstáculo artificial que revele o ilegítimo, arbitrário e censurável propósito de fraudar, de frustrar e de inviabilizar o estabelecimento e a preservação, em favor da pessoa e dos cidadãos, de condições materiais mínimas de existência. Cumpre advertir, desse modo, que a cláusula da "reserva do possivel" - ressalvada a ocorrência de justo motivo objetivamente aferível - não pode ser invocada, pelo Estado, com a finalidade de exonerar-se do cumprimento de suas obrigações constitucionais, notadamente quando, dessa conduta governamental negativa, puder resultar nulificação ou, até mesmo, aniquilação de direitos constitucionais impregnados de um sentido de essencial fundamentalidade. [...]

Não obstante a formulação e a execução de políticas públicas dependam de opções políticas a cargo daqueles que, por delegação popular, receberam investidura em mandato eletivo, cumpre reconhecer que não se revela absoluta, nesse domínio, a liberdade de conformação do legislador, nem a de atuação do Poder Executivo.

É que, se tais Poderes do Estado agirem de modo irrazoável ou procederem com a clara intenção de neutralizar, comprometendo-a, a eficácia dos direitos sociais, econômicos e culturais, afetando, como decorrência causal de uma injustificável inércia estatal ou de um abusivo comportamentogovernamental, aquele núcleo intangívelconsubstanciador de um conjunto irredutivel de condições mínimas necessárias a uma existência digna e essenciais à própria sobrevivência do indivíduo, aí, então, justificar-se-á, como precedentemente já enfatizado - e até mesmo por razões fundadas em um imperativo ético-jurídico -, a possibilidade de intervenção do Poder Judiciário, em ordem a viabilizar, a todos, o acesso aos bens cuja fruição Ihes haja sido injustamente recusada pelo Estado. (Grifos nossos)

Esse discurso, nos precedentes que Ihe seguiram, foi utilizado para determinar a órgãos do Poder Executivo do Estado brasileiro, em diferentes níveis federativos, que, dentre outras atividades:48 ampliem o acesso a creches escolares e outros

\footnotetext{
48 Estou, de forma propositada, desprezando, nesses exemplos, os precedentes que entendem possível determinar o fornecimento, pelos entes estatais, de medicamentos a pessoas específicas. Nessas demandas, comumente não se discute a política pública de saúde, mas apenas uma prestação específica de uma política já bem regulamentada em nível infraconstitucional. Quando falta, nas prateleiras dos órgãos que compõem o sistema único de saúde, um remédio que deveria ser ofertado pelo Poder Público e, para a sua concessão, é aforada uma ação, está-se requerendo o cumprimento de uma política desenvolvida e em funcionamento. Em uma simplificação, pode-se dizer que o raciocínio se desenvolve por meio do seguinte silogismo: o Estado obrigou-se a fornecer, por meio do SUS, determinado fármaco (premissa maior), o particular pediu administrativamente mas não o obteve (premissa menor) e então o Poder Judiciário determina que a Administração Pública cumpra uma obrigação que ela própria se impôs. A situação é bem diferente quando se trata de ações civis públicas ajuizadas com a pretensão de fazer incluir, no âmbito do SUS, para fornecimento gratuito a todos os potenciais beneficiários, uma nova droga, de caráter, por exemplo, experimental, não aprovada pela Anvisa, mas que seja defendida por parte da comunidade médica como eficaz para o tratamento de uma doença cuja medicação não esteja prevista para dispensação pelo Poder Público. Aí sim podemos falar em judicialização de uma política pública de saúde, a demandar uma interpretação muito mais complexa do fenômeno.
} 
estabelecimentos de educação infantil (RE no 410.715, RE nํ 436.996, ARE no 639.337 e RE no 595.595); forneçam transporte a alunos da rede pública de ensino (RE no 603.575); construam salas de aula (ARE no 635.679); regularizem moradias populares (AI $\mathrm{n}$ - 708.667); realizem obras para tratamento de esgoto (AI 5 no 93.676) e para despoluição de um rio ( $R E$ no 417.408); paguem diferenças referentes aos serviços efetivamente prestados aos beneficiários do SUS por entidade médica privada, mesmo que extrapolado o teto orçamentário previsto (RE no 665.764); construam abrigos para moradores de rua ( $R E$ no 634.643); reformem instituição de ensino (Al no 809.018); cumpram adequada e continuamente serviços de saúde em âmbito municipal, promovendo a reforma, a manutenção geral e a pintura de estabelecimento médico, a aquisição de condicionadores de ar, a reativação de salas de cirurgia e de parto, a reforma na rede elétrica, a aquisição de extintores de incêndio e mangueiras e a contratação efetiva de farmacêutico ou bioquímico (RE no 642.536); promovam a demolição de construções em desacordo com o projeto urbanístico (RE no 563.144); realizem obras de saneamento (RE № 700.227); ampliem a atuação da Defensoria Pública (AI no 835.956, RE № 763667, RE o 795.749, Al no 598.212 e Al no 739.151); destaquem policiais para garantia da segurança em estabelecimento de custódia de menores infratores (Al no 810.410); incrementem estruturas em maternidades estaduais (RE no 581.352); aumentem leitos em unidade de terapia intensiva (ARE № 740.800); recuperem barragem (RE no 658.171); assegurem o direito à educação, em local com infraestrutura básica, a menores residentes em assentamentos (RE no 595.129); construam nova escola e contratem vigia (ARE o 761.127).

Esses casos são exemplificativos, não representam a totalidade dos precedentes, mas dão uma boa dimensão da problemática. É interessante notar que há situações nas quais sequer se consegue aferir, com precisão, o tipo de política pública com que o Supremo Tribunal Federal está lidando, porquanto esse "dado" não é detalhado na fundamentação, que acaba resumida à enunciação das "diretrizes" que a jurisprudência da Corte enuncia como autorizativas do controle judicial de políticas públicas. Isso ocorreu nos casos dos recursos extraordinários nํㅗ 628.159, 723.578 e 768.825. 0 que se pode inferir desses precedentes é apenas que cuidavam de ações no âmbito de políticas de segurança pública.

À vista desse quadro, é possível postular que a jurisprudência do Supremo Tribunal Federal sobre controle de políticas públicas não se legitima reflexivamente, falhando, portanto, na tentativa de representar o "povo princípio", muito embora adote uma espécie de perfeccionismo interpretativo. Uma análise desse tipo pode ser feita de variadas formas. Daremos destaque, neste artigo, ao fato de que os precedentes afastam completamente o "mundo prático" do direito e à circunstância de que não constroem a sua cadeia de julgados com "integridade". 
$\mathrm{Na}$ referida ADPF $\mathrm{n}$ 45, que inaugurou o entendimento do STF, com recorte perfeccionista, sobre o controle judicial de políticas públicas, o Ministro Celso de Mello não enfrentou o mérito da lide. Ele declarou a ação prejudicada em virtude da perda superveniente do objeto. É curioso constatar que todas aquelas considerações ambiciosas foram feitas em obiter dictum, o que não impediu que fossem reproduzidas em diversos precedentes formados posteriormente. Esse é um dado relevante para o exame que pretendemos fazer aqui, pois, se o mérito da ação não foi julgado, as exortações de princípio feitas pelo ministro ocorreram em abstrato, com o absoluto afastamento da faticidade, do mundo prático. A pretensão foi a de tomar posição em amplas controvérsias sociais, mesmo sem apreciar as nuances fáticas do problema posto. Houve como que um descolamento da realidade. Celso de Mello falou sobre direitos fundamentais, reserva do possível, mínimo existencial, mas, da forma como o fez, tão vaga e abstratamente, não nos possibilita discernir quando e até que ponto o Estado estará descumprindo, na prática, a principiologia constitucional e quando estará agindo dentro dos limites legítimos proporcionados por determinadas interpretações dos postulados genéricos que Ihe balizam o atuar. Em uma palavra: houve um esquecimento de que os princípios introduzem o mundo prático no direito, e não dele (do mundo prático) o afastam.

Assim, ao aplicar o texto constitucional “sozinho", sem fundi-lo hermeneuticamente com os limites e possibilidades do Estado Social naquele contexto, acabou aplicando uma teoria da Constituição (puramente normativa) sem teoria do Estado (mundo prático). Essa conduta do ministro não é reflexivamente legítima, ficando vulnerável às críticas externadas há tempo, em âmbito teórico, por um dos autores deste texto, Bolzan de Morais, e por Lenio Streck, ${ }^{49}$ para quem a teoria do Estado é "condição de possibilidade para o estudo do Direito Constitucional". Da mesma forma, às críticas de Gilberto Bercovici, que entende haver uma "crise atual na teoria da Constituição" (a ADPF no 45 parece ser um sintoma disso), que só poderá ser superada se "entendermos a Constituição dentro dos pressupostos da Teoria do Estado, em conexão com a política e a realidade social”. ${ }^{50}$ Do pensamento deste último autor, destacamos, por oportuno, mais um trecho: 51

49 STRECK, Lenio Luiz. Hermenêutica jurídica e $(m)$ crise. Uma exploração hermenêutica da construção do direito. 8. ed. Porto Alegre: Livraria do Advogado, 2009.

50 BERCOVICl, Gilberto. Teoria do Estado e teoria da Constituição na periferia do capitalismo: breves indagações críticas. In: NUNES, Antônio José Avelãs; COUTINHO, Jacinto Nelson de Miranda (Orgs.). Diálogos constitucionais: Brasil/Portugal. Rio de Janeiro: Renovar, 2004. A crítica dessa teoria - diga-se assim "asséptica" da Constituição é trabalhada por autores de variadas vertentes, que atribuem esse equívoco às ideias do "neoconstitucionalismo". Tal discussão não precisará ser abordada neste momento, mas fica o registro de alguns textos que adotam, no contexto desse debate, uma perspectiva semelhante à ora defendida: LIMA, Martônio Mont'Alverne Barreto. Constituição e política: o materialismo da Constituição. In: BELLO, Enzo; LIMA et al (Orgs.). Direito e marxismo: tendências atuais. Caxias do Sul: Educs, 2012; LIMA, Martônio Mont'Alverne Barreto. Subdesenvolvimento e Constituição dirigente: uma possível abordagem materialista. In: BELLO, Enzo; LIMA, Martônio Mont'Alverne Barreto (Orgs.). Direito e marxismo. Rio de Janeiro: Lumen Juris, 2010; VERDÚ, Pablo Lucas. La Constitución en la encrucijada (palingenesia iuris politici). Revista Pensamiento Constitucional, v. 4, n. 4, p. 69-139, 1997.

51 BERCOVICI, Gilberto. Constituição e política: uma relação difícil. Revista Lua Nova, n. 61, p. 5-24, 2004. 
Fechando os olhos para a realidade constitucional, o pensamento jurídico dominante absolutizou as soluções constitucionais históricas do liberalismo como atemporais. Para não cair neste equívoco, a Teoria da Constituição deve ser entendida na lógica das situações concretas históricas de cada país, integrando em um sistema unitário a realidade histórico-política e a realidade jurídica. O direito constitucional recupera, assim, segundo Pedro de Vega García, as categorias de espaço e tempo e adquire dimensões concretas e históricas. A Constituição não pode ser entendida como entidade normativa independente e autônoma, sem história e temporalidade próprias. Não há uma Teoria da Constituição, mas várias teorias da Constituição, adequadas à sua realidade concreta. A Constituição não deve apenas estar adequada ao tempo, mas também ao espaço. Sem entender o Estado, não há como entender a Constituição, o que desqualifica a constante hostilidade da Teoria da Constituição contra o Estado.

Essa "assepsia" constitucional pode provocar um fenômeno denunciado por Luciano Violante, cuja imagem é a da transformação de direitos em desejos. Em um pequeno livro de 2014, /l dovere di avere doveri, esse autor confronta a mudança paradigmática sofrida no modelo de democracia com uma "política dos direitos", em estreita conexão com a atividade jurisdicional. ${ }^{52}$ Preocupado com uma judicial dictatorship, Violante põe em confronto essa lotta per i diritti com aquela de uma età dei doveri, tentando reequilibrar a "balança democrática" entre direitos e deveres. Dito de outro modo, retoma o conceito de "dever" como meio para (re) construir a ideia de democracia, a qual exige, para ele, um sentido de cidadania alicerçado na obrigação política e em uma rede de relações cívicas e não apenas em direitos em torno dos quais se constrói uma disputa excludente. Nesse quadro, os juízes assumiriam, segundo o autor, uma nova roupagem: passam de garantidores a criadores de direitos, contribuindo, assim, para aquilo que passou a ser chamado como costituzione infinita e pondo em xeque a forma de governo, subtraindo as políticas públicas das maiorias parlamentares, eleitas e responsáveis, e transferindoas para a "tecnocracia das jurisdições". ${ }^{53}$

É perfeitamente possível aproximarmos essas reflexões do ponto trabalhado pelos teóricos do Estado citados na primeira parte deste estudo, que insistem em marcar a existência de limites no Estado Social de Direito. Ora, quando o Poder Judiciário determina a canalização de recursos do erário para o cumprimento de

\footnotetext{
52 VIOLANTE, Luciano. I/ dovere di avere doveri. Torino: Giulio Einaudi Editore, 2014. Como refere: “L'espansione tendenzialmente illimitata dei diritti, separata dalla valorizzazione dei doveri, e potenziata dalla crescente giurisdizionalizzazione, non costituiscono un rimedio, ma rappresentano le manifestazioni piú evidenti delle difficoltà della democrazia costituzionale. Si affiancano altre manifestazioni patologiche, quali la ricerca demagogica del consenso, il populismo, la spettacolarizzazione" (p. XIV).

53 Para Violante, a politica dei diritti, que se inaugura como uma preocupação pelos "destinos" da democracia, "si conclude con soluzioni ispirate a una sorta di neogoverno globale dei tecnici, questa volta giuristi eno economisti, non compatibile con i principl̂ dela democrazia politica” (p. 19).
} 
decisões veiculadoras de significativas ordens materiais dirigidas aos entes políticos da Federação, muito provavelmente alguém ou algum serviço será, em face dos inerentes limites do Estado Social, preterido. E, pelo descolamento da decisão com a facticidade, a preterição possivelmente havida não será controvertida no caso, gerando a impressão de que não existiu. Considerado o princípio da igualde, é bem evidente o problema de criar-se uma tradição jurisprudencial de controle de políticas públicas situadas apenas ao nível da normatividade abstrata da Constituição, sem tencioná-la com alguma teoria do Estado. Não obstante, é precisamente esse o padrão jurisprudencial assumido pelo Supremo Tribunal Federal no período pós-ADPF no 45, pela simples e direta incorporação das ilações tecidas pelo Ministro Celso de Mello aos casos subsequentes, ilações essas que, apesar de realizadas em sede de obiter dictum, acabaram cristalizadas em muitas e sucessivas razões de decidir.

Também se enfocarmos a problemática sob a ótica da necessidade de o direito observar a "integridade" na sua construção, haverá um déficit de legitimidade por reflexividade na jurisprudência do Supremo sobre o controle judicial de políticas públicas. Para essa análise, seria necessária uma recondução interpretativa ao ponto inicial da história dessa jurisprudência. Como vimos, não parece ser possível fazê-lo com muita segurança. A primeira referência encontrada acerca do atual entendimento da Corte é a ADPF o 45. E se esse marco efetivamente for o início da história jurisprudencial, já teríamos dificuldades com duas questões: a decisão nela proferida não abordou propriamente uma controvérsia e a parte do discurso sistematicamente reproduzida foi toda tecida, ao estilo perfeccionista, desconectada do mundo prático. Como dizer então que houve a construção de um "romance em cadeia", a partir desse "capítulo original"?

E é interessante observar que, a despeito de toda essa jurisprudência perfeccionista, permanecem sendo proferidas decisões monocráticas de ministros entendendo não ser possível ao Poder Judiciário imiscuir-se em políticas públicas por conta do princípio da separação dos poderes da República. Em uma rápida pesquisa na base de decisões monocráticas do seu site, podemos identificar que o STF tem julgados recentes entendendo pela impossibilidade de o Poder Judiciário compelir o Poder Executivo a construir ou reformar penitenciárias, matéria inserta na área das políticas de segurança pública. São todos pronunciamentos unipessoais. Provêm de ministros diversos e datam de períodos distintos, mas são contemporâneos à jurisprudência ora em exame (de 2005 a 2011). ${ }^{54}$ Cumpre-nos transcrever alguns excertos de pelo menos um deles, até porque as decisões adotam a chamada "motivação per relationem", isto é, reportam-se aos fundamentos das anteriores.

\footnotetext{
54 São os pronunciamentos exarados nos seguintes recursos extraordinários: RE nํ 279.455 (Ministra Ellen Gracie), RE no 365.299 (Ministro Carlos Velloso), RE no 403.806 (Ministro Cezar Peluso) e RE n 422.298 (Ministro Eros Grau). Disponíveis em: <http://www.stf.jus.br>. Acesso em: 31 ago. 2014.
} 
A decisão escolhida é da Ministra Cármen Lúcia (RE no 650.085), que faz um apanhado das demais, sendo, portanto, bem ilustrativa dessa cadeia de julgados. Eis os seus trechos mais significativos: ${ }^{55}$

[...] Analisados os elementos havidos nos autos, DECIDO. [...]

4. Este Supremo Tribunal assentou que a determinação, pelo Poder Judiciário, de realização de obras em cadeia pública contraria o art. $2^{\circ}$ da Constituição da República: [...]

6. Todavia, no que concerne à violação ao art. $2^{\circ}$ da Constituição Federal, assiste razão à parte recorrente, consoante a jurisprudência do Supremo Tribunal Federal. O Min. Eros Grau bem ressaltou sobre a matéria no RE 422.298/PR, DJ 07.8.2006, nos seguintes termos:

“3. A forma como o Estado-membro vai garantir o direito à segurança pública há de ser definida no quadro de políticas sociais e econômicas cuja formulação é atribuição exclusiva do Poder Executivo. Não cabe ao Judiciário determinar a realização de obras em cadeia pública. Nesse sentido, o RE n. 365.299, Relator o Ministro Carlos Velloso, DJ de 9.12.05."

Ainda, nesse sentido cito o RE 403.806/PR, rel. Min. Cezar Peluso, DJ 22.8.2007 e o RE 401.758/GO, rel. Min. Gilmar Mendes, DJe 06.3.2008. [...]

9. De fato, a utilização de ação civil pública a fim de exigir do Executivo local a manutenção de determinado estabelecimento prisional afigurase um questionável avanço em suas atribuições, pois, apesar de ser nobre o pleito e de a segurança pública ser deveras direito de todos, esse tipo de ingerência nos atos da Administração pública pode acabar por transformar o juiz em administrador, uma vez que os recursos orçamentários são geralmente escassos e as necessidades humanas infinitas. [...]

Dessa orientação jurisprudencial divergiu o julgado recorrido.

5. Pelo exposto, dou provimento ao recurso extraordinário (art. 557, 1--A, do Código de Processo Civil e art. 21, §2º, do Regimento Interno do Supremo Tribunal Federal).

Publique-se.

Brasília, 1ํ de setembro de 2011.

Ministra CÁRMEN LÚCIA

Não foi apresentada explicação para o discrímen em relação aos demais precedentes sobre políticas públicas. Por que apenas nesses casos foi adotada uma postura minimalista, atrelada ao princípio da separação dos poderes? A falta de coerência entre esses julgados e os demais viola a "integridade do Direito", na expressão de Ronald Dworkin. E mesmo nesses julgados não há uma conexão da normatividade com o mundo prático. O princípio da separação dos poderes foi invocado

$\overline{55}$ Disponível em: <http://www.stf.jus.br>. Acesso em: 31 ago. 2014. 
sem ser densificado por aspectos da realidade presentes nas controvérsias. 0 que existe, nos precedentes do Supremo Tribunal Federal, parece ser um mero conflito entre discursos: de um lado, aquele que sustenta a possibilidade de o Poder Judiciário intervir em políticas públicas, desde que para fazer cumprir direitos fundamentais, o mínimo existencial, a dignidade humana etc.; de outro, o que assume uma postura de autocontenção, entendendo violadoras do princípio da separação de poderes ordens judiciais que disponham sobre a (in)adequação de políticas públicas, pois "a forma como o Estado-membro vai garantir o direito à segurança pública há de ser definida no quadro de políticas sociais e econômicas cuja formulação é atribuição exclusiva do Poder Executivo". Isso tudo indica que, também sob um enfoque dworkiniano, falta reflexividade aos julgados examinados para se legitimarem.

O Supremo Tribunal Federal, portanto, por estar atuando, no tocante ao controle de políticas públicas, sem incorporar a faticidade do direito (representada, nessas situações, por uma teoria do Estado Social que dê conta de seus limites e possibilidades) e sem se comprometer ou, pelo menos, trabalhar com seus próprios precedentes, deixou de representar o "povo princípio". Se o critério de sua legitimidade fosse o majoritário, teria condições de determinar a alocação de recursos dessa forma, porquanto estaria agindo, mesmo que em um plano formal, autorizado por aqueles que depositaram os votos na urna, pelo "povo eleitoral". Mas ele deve representar - permitimo-nos insistir no ponto - o "povo princípio" e, por isso, sua legitimidade opera em chave diversa, reflexivamente. Daí podermos afirmar que os precedentes do Supremo Tribunal Federal sobre controle judicial de políticas públicas, à luz das premissas colocadas neste estudo, estão equivocados.

\section{Conclusão}

As palavras aqui redigidas pretenderam apenas colocar uma provocação. Há muita reflexão a ser feita sobre os diversos aspectos que se relacionam ao tema da judicialização de políticas públicas. Porém, parece-nos que qualquer abordagem que se faça da questão deve necessariamente passar, ainda que de forma implícita, pelo problema dos limites do Welfare State e pelo debate sobre a legitimidade do Poder Judiciário para lidar com as complexas demandas sobre o assunto. Deveras, o embate entre função de governo e função de garantia, em torno das prestações materiais exigiveis do Estado, põe em xeque a clássica tripartição de poderes, uma vez que tem, como pano de fundo, a discussão entre o mínimo existencial e a reserva do possível, discussão essa margeada "pelo fundamento da dignidade da pessoa humana no contexto de um Estado que, apesar de social, não rompeu com o modelo econômico - capitalismo - cujo fundamento não é, por óbvio, o da inclusão social". ${ }^{56}$

\footnotetext{
56 MORAIS, José Luis Bolzan de. As crises do Estado e da Constituição e a transformação espaço-temporal dos direitos humanos. 2. ed. Porto Alegre: Livraria do Advogado, 2011. p. 868-884. Edição Kindle.
} 
Apesar desse diagnóstico, não se pode perder de perspectiva, com Avelãs Nunes, que aos tribunais continua não cabendo "fazer política, substituindo-se aos demais órgãos do Estado aos quais cabe essa função". ${ }^{57}$ Daí o valor da proposta de Pierre Rosanvallon, que classifica a legitimidade em tipos distintos daquela de recorte eleitoral-majoritária. A legitimidade por reflexividade, requisito preponderante de aceitação da autoridade dos juízes, é uma boa ferramenta para a feitura de um exame qualitativo das decisões proferidas pelo Poder Judiciário.

A conclusão geral a que pudemos chegar, dentro do objeto delimitado pelos necessários cortes metodológicos, é que a cadeia de precedentes do Supremo Tribunal Federal sobre controle de políticas públicas apresenta um preocupante déficit de legitimidade, entendida esta no sentido reflexivo. Não podemos afirmar que o resultado das decisões que impõem aos distintos entes federados a execução dessas variadas prestações materiais é justo ou injusto, bom ou ruim. Mas a nossa preocupação, como pretendemos ter deixado claro, está precisamente aí, ou seja, na impossibilidade de realizar essa aferição dos resultados, pela irracionalidade da forma como os precedentes estão sendo construídos, sem compromisso com a coerência e a integridade do direito, tampouco com o resgate do mundo prático através dos princípios. É como se a Corte Constitucional estivesse julgando, um tanto aleatoriamente, ações de um Estado Social que não possui limites, que desconhece crises.

Welfare State and its limits, the legitimacy of reflexivity, and the judicial review of public policies in the Brazilian Supreme Court

Abstract: This paper discusses the judicial review of public policies in the Brazilian Supreme Court. The parameters are texts of authors who write about the limits and crises of the Welfare State and the concept of legitimacy of reflexivity (Pierre Rosanvallon). The hypothesis is that the precedents of the Supreme Court that deal with public policy present a deficit of legitimacy. These cases are intended to be perfectionists, but fail to incorporate the facticity through the principles and to respect the integrity of Law. This means that these cases do not observe the legitimacy of reflexivity.

Keywords: Welfare State and its limits. Public policies. Legitimacy of reflexivity. Brazilian Supreme Court.

\section{Referências}

BERCOVICI, Gilberto. Constituição e política: uma relação difícil. Revista Lua Nova, n. 61, p. 5-24, 2004.

BERCOVICl, Gilberto. Teoria do Estado e teoria da Constituição na periferia do capitalismo: breves indagações críticas. In: NUNES, Antônio José Avelãs; COUTINHO, Jacinto Nelson de Miranda (Orgs.). Diálogos constitucionais: Brasil/Portugal. Rio de Janeiro: Renovar, 2004.

\footnotetext{
57 NUNES, António José de Avelãs; SCAFF, Fernando Facury. Os tribunais e o direito à saúde. Porto Alegre: Livraria do Advogado, 2011. p. 957. Edição Kindle.
} 
BRUM, Guilherme Valle. Uma teoria para o controle judicial de políticas públicas. Rio de Janeiro: Lumen Juris, 2014.

DWORKIN, Ronald. O império do direito. Tradução de Jefferson Luiz Camargo. São Paulo: Martins Fontes, 2007.

DWORKIN, Ronald. Uma questão de princípio. Tradução de Luís Carlos Borges. São Paulo: Martins Fontes, 2005.

FERNANDEZ-SAVATER, Amador. Fuera de lugar. Conversaciones entre crisis e transformación. Madrid: Acuarela y Machado Grupo de Distribución, 2013.

HELD, David. Cosmopolitismo. Ideales y realidades. Tradução de Dimitri Fernández Bobrovski. Madrid: Alianza Editorial, 2012.

KERSTENETZKY, Celia Lessa. Estado do Bem-Estar Social na Idade da Razão. A reinvenção do Estado Social no mundo contemporâneo. Rio de Janeiro: Elsevier, 2012.

LIMA, Martônio Mont'Alverne Barreto. Constituição e política: o materialismo da Constituição. In: BELLO, Enzo; LIMA et al (Orgs.). Direito e marxismo: tendências atuais. Caxias do Sul: Educs, 2012.

LIMA, Martônio Mont'Alverne Barreto. Subdesenvolvimento e Constituição dirigente: uma possível abordagem materialista. In: BELLO, Enzo; LIMA, Martônio Mont'Alverne Barreto (Orgs.). Direito e marxismo. Rio de Janeiro: Lumen Juris, 2010.

MORAIS, José Luis Bolzan de. As crises do Estado e da Constituição e a transformação espaço-temporal dos direitos humanos. 2. ed. Porto Alegre: Livraria do Advogado, 2011. Edição Kindle.

MORAIS, José Luis Bolzan de. Crise do Estado e democracia. Onde está o povo? In: LIMA, Martonio Mont'Alverne Barreto; ALBUQUERQUE, Paulo Antonio de Menezes (Org.). Democracia, direito e política: estudos internacionais em homenagem a Friedrich Müller. Florianópolis: Conceito Editorial, 2006.

MORAIS, José Luis Bolzan de; STRECK, Lenio Luiz. Ciência política e teoria geral do Estado. 4. ed. Porto Alegre: Livraria do Advogado, 2004.

MÜLLER, Friedrich. Quem é o povo? A questão fundamental da democracia. Tradução de Peter Naumann. 3. ed. São Paulo: Max Limonad, 2003.

NUNES, António José Avelãs. O estado capitalista e as suas máscaras. 2. ed. Rio de Janeiro: Lumen Juris, 2013.

NUNES, António José de Avelãs; SCAFF, Fernando Facury. Os tribunais e o direito à saúde. Porto Alegre: Livraria do Advogado, 2011. Edição Kindle.

RODOTÀ, Stefano. I/ diritto di avere diritti. Roma: Laterza, 2012.

ROSANVALLON, Pierre. A crise do Estado-providência. Tradução de Joel Pimentel de Ulhôa. Goiânia: UFG, 1997.

ROSANVALLON, Pierre. A nova questão social. Repensando o Estado Providência. Tradução de Sérgio Bath. Brasília: Instituto Teotônio Vilela, 1998.

ROSANVALLON, Pierre. La legitimidad democrática. Imparcialidad, reflexividad y proximidad. Tradução de Heber Cardoso. Barcelona: Paidós, 2010.

SASSEN, Saskia. Territorio, autoridad y derechos. De los ensamblajes medievales a los ensamblajes globales. Tradução de María Victoria Rodil. Madrid: Katz Editores, 2010.

SORENSEN, Georg. La transformación del Estado. Mas allá del mito del repliegue. Tradução de Ramón Cotarelo. Valencia: Tirant lo Blanch, 2010.

STRECK, Lenio Luiz. Hermenêutica jurídica $e(m)$ crise. Uma exploração hermenêutica da construção do direito. 8. ed. Porto Alegre: Livraria do Advogado, 2009. 
STRECK, Lenio Luiz. Verdade e consenso. Constituição, hermenêutica e teorias discursivas. Da possibilidade à necessidade de respostas corretas em Direito. 3. ed. Rio de Janeiro: Lumen Juris, 2009.

SUNSTEIN, Cass. Radicals in robes: why extreme right-wing courts are wrong for America. New York: Basic Books, 2005. Edição Kindle.

VERDÚ, Pablo Lucas. La Constitución en la encrucijada (palingenesia iuris politici). Revista Pensamiento Constitucional, v. 4, n. 4, p. 69-139, 1997.

VIOLANTE, Luciano. Il dovere di avere doveri. Torino: Giulio Einaudi Editore, 2014.

Informação bibliográfica deste texto, conforme a NBR 6023:2002 da Associação Brasileira de Normas Técnicas (ABNT):

MORAIS, José Luis Bolzan de; BRUM, Guilherme Valle. Estado Social, legitimidade democrática e o controle de políticas públicas pelo Supremo Tribunal Federal. $A \& C$ - Revista de Direito Administrativo \& Constitucional, Belo Horizonte, ano 16, n. 63, p. 107-136, jan./mar. 2016.

Recebido em: 29.05.2015

Aprovado em: 03.07.2015 